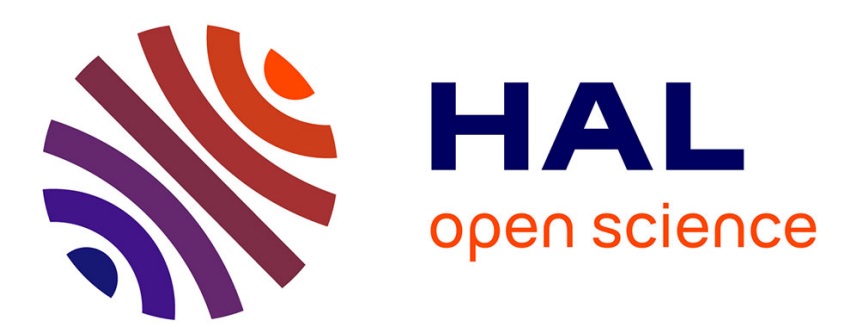

\title{
Inverse ductile thinning via lower crustal flow and fold-induced doming in the West Carpathian Eo-Alpine collisional wedge
}

\author{
Jerabek Petr, O. Lexa, Karel Schulmann, Dusan Plasienka
}

\section{- To cite this version:}

Jerabek Petr, O. Lexa, Karel Schulmann, Dusan Plasienka. Inverse ductile thinning via lower crustal flow and fold-induced doming in the West Carpathian Eo-Alpine collisional wedge. Tectonics, 2012, 31, pp.TC5002. hal-00737842

\section{HAL Id: hal-00737842 \\ https://hal.science/hal-00737842}

Submitted on 29 Nov 2021

HAL is a multi-disciplinary open access archive for the deposit and dissemination of scientific research documents, whether they are published or not. The documents may come from teaching and research institutions in France or abroad, or from public or private research centers.
L'archive ouverte pluridisciplinaire $\mathbf{H A L}$, est destinée au dépôt et à la diffusion de documents scientifiques de niveau recherche, publiés ou non, émanant des établissements d'enseignement et de recherche français ou étrangers, des laboratoires publics ou privés.

$$
\text { Copyright }
$$




\title{
Inverse ductile thinning via lower crustal flow and fold-induced doming in the West Carpathian Eo-Alpine collisional wedge
}

\author{
P. Jeřábek, ${ }^{1}$ O. Lexa, ${ }^{1,2}$ K. Schulmann, ${ }^{2,3}$ and D. Plašienka ${ }^{4}$ \\ Received 17 January 2012; revised 3 August 2012; accepted 8 August 2012; published 25 September 2012.
}

[1] Continental core complexes are generally interpreted to result from extensional doming due to gravity-driven upflow of lower crust. In contrast, the Vepor Dome is characterized by the lack of inverted density profile and relatively cold metamorphic field gradient which precludes an activation of Rayleigh-Taylor instability. Instead, the crustal structure of the Vepor Unit is marked by dense and weak metapelitic lower crust and light and strong granitoid upper crust inherited from Variscan nappe stacking. It is shown that the Cretaceous Eo-Alpine tectonic evolution of the Vepor Dome is controlled by the dynamics of two neighboring mechanically strong continental blocks, i.e., the overthrusting of the suprastructural Gemer Unit from the south and the underthrusting of the Fatric basement from the north. Structural, metamorphic and geochronological data from the Vepor Unit imply two main phases of the convergent process: (1) Lower Cretaceous crustal thickening due to overthrusting and internal deformation of the Gemer Unit together with upper crustal folding in the Vepor Unit led to the progressive development of the orogenic front parallel pressure gradient. The instantaneous response of the lower crustal and low-viscosity metapelites led to an along-strike lower crustal flow accompanied by prograde Barrovian-type metamorphism. (2) As the south vergent underthrusting of the Fatric basement propagated to greater depths during the Upper Cretaceous, the convergent process switched from top driven to bottom driven, and the exhumation of the lower crust occurred via polyharmonic folding. Overall doming of the Vepor Unit induced upper crustal detachment faulting and eastward unroofing of the dome.

Citation: Jeřábek, P., O. Lexa, K. Schulmann, and D. Plašienka (2012), Inverse ductile thinning via lower crustal flow and foldinduced doming in the West Carpathian Eo-Alpine collisional wedge, Tectonics, 31, TC5002, doi:10.1029/2012TC003097.

\section{Introduction}

[2] The genesis of dome-like structures in orogenic and postorogenic settings is critically dependent on the relative contribution of far field and body forces, their spatial arrangement, and physical state of the lithosphere. Dome structures are typically associated with three main tectonic settings characterized by variable contributions from tensile, compressive and gravity forces. These are (1) typical core complexes developing in continuously extending back arc regions (tensile and gravity), (2) elongate domes characterized by orogen-parallel extension originating from collisional shortening and associated tectonic escape (compressive and tensile), and (3) intraplate mantled gneiss domes characterized

\footnotetext{
${ }^{1}$ Institute of Petrology and Structural Geology, Charles University, Prague, Czech Republic.

${ }^{2}$ Now at Centre for Lithospheric Research, Czech Geological Survey, Prague, Czech Republic.

${ }^{3}$ EOST, UMR 7516, Université de Strasbourg, Strasbourg, France.

${ }^{4}$ Department of Geology and Paleontology, Comenius University, Bratislava, Slovakia.

Corresponding author: P. Jeřábek, Institute of Petrology and Structural Geology, Charles University, Albertov 6, CZ-12843 Prague 2, Czech Republic. (jerabek1@natur.cuni.cz)

C2012. American Geophysical Union. All Rights Reserved. 0278-7407/12/2012TC003097
}

by buoyant crust associated with hot orogens or orogenic climax (compressive and/or gravity).

[3] Typical core complexes (setting 1) are asymmetrical horst-like structures or elliptical domes characterized by trench-perpendicular extension in the hanging wall of retreating subducting plate. As a result, the generally thickened crust is massively extended at medium/high temperature (MT/HT) and low pressure (LP) with some crustal melting. Typical examples are the Aegean Sea [Lister et al., 1984; Jolivet et al., 1994] and the Basin and Range province [Coney, 1987; Lister and Davis, 1989].

[4] Orogen parallel extensional domes (setting 2) are strongly elliptical dome structures with their long axes parallel to the collisional front and extension direction. These intraorogenic domes are associated with exhumation of MTMP rocks, some syntectonic to posttectonic magmatism, and both symmetric and asymmetric detachments formed perpendicular to the collisional front. Typical examples are the Tauern Window in the Eastern Alps [Selverstone, 1988; Ratschbacher et al., 1991], the Danubian Window in the South Carpathians [Schmid et al., 1998; Fügenschuh and Schmid, 2005], and the Amma Drime horst-type dome [Kali et al., 2010] exhuming deep rocks in the direction of lateral extrusion of the Tibetan Plateau [Dewey et al., 1989; Zhang et al., 2004]. 
[5] Mantled gneiss domes (setting 3) are weakly elliptical to circular structures typically found in the central parts of large hot orogens. These domes originate due to crustal folding and/or gravity-driven crustal redistribution [Burg et al., 2004] juxtaposing the high-grade domal core and almost unmetamorphosed mantle. They are associated with HT-MP conditions, adiabatic decompression and extensive partial melting. Typical field examples are represented by diapiric structures in the trondhjemite-tonalite- granodiorite (TTG) greenstone belts of Archean and Meso Proterozoic orogens [e.g., Perchuk et al., 1985; Brown and Talbot, 1989], gneiss domes in the Variscan Orogen in Europe [Burg et al., 1994; Vanderhaeghe et al., 1999; Lexa et al., 2011] and the Tertiary Canadian Cordillera [Teyssier and Whitney, 2002].

[6] The Vepor Dome in the West Carpathians represents a crustal-scale, $100 \mathrm{~km}$ long and $50 \mathrm{~km}$ wide gneiss dome emerging through the Mesozoic nappe system. This dome is located in the core of the Cretaceous Eo-Alpine Central West Carpathian orogenic wedge [Plašienka et al., 1997] and has been interpreted as a core complex [Janák et al., 2001] or orogen parallel extensional dome [Plašienka et al., 1997]. In contrast, Jeřábek et al. [2008a] suggested that the geometry of the Vepor Dome may originate from crustal-scale folding.

[7] Based on a robust structural database and detailed structural and petrological characterization of the Vepor Dome combined with a large data set of available geochronological data, we propose a set of distinctive criteria to identify a new type of crustal dome. Here, we take into account the thickening history as a necessary precursor to the development of domal structure. The differing sequences of fabric superposition at different crustal levels within the Vepor Dome combined with contemporaneous P-T records allow us to connect suprastructural thickening with synburial thinning in the deep crust. The contrasting records of exhumation in the deep and shallow parts of the dome point to multiscale upright folding and upper crustal ductile thinning mechanisms driving the growth and destruction of the dome.

\section{Geotectonic Setting}

[8] The West Carpathians form the northernmost arcuate segment of the European Alpine mountain system that connects the Eastern Alps to the west and the East Carpathians to the east (Figure 1a). The Central West Carpathians (Figure 1b) can be divided into two major tectonic realms based on distinct Paleozoic-Mesozoic evolution indicated by differences in basement structure and lithology, Mesozoic basin evolution, and the presence of nappes derived from the Meliata Ocean. The southern realm, represented by the Gemer Unit (Figures $1 \mathrm{~b}$ and 1c), is similar to the Upper Austroalpine units of the Eastern Alps [Neubauer et al., 2000]. The Gemer Unit consists of basement Variscanmetamorphosed Lower Paleozoic volcano-sedimentary sequences and Carboniferous-Permian continental and marine cover sediments [Vozárová and Vozár, 1988; Faryad, 1991; Soták et al., 1999]. It is tectonically overlain by the nappes of the Late Jurassic subduction-accretionary complex of the Meliata Ocean [Kozur and Mock, 1973; Faryad and Henjes-Kunst, 1997]. The northern realm shows a basement and cover structure typical for the Middle Austroalpine units [Neubauer et al., 2000]. In the northern realm, the basement is formed by Variscan high-grade gneisses and granitoids of the northern
Tatra and southern Vepor units (Figure 1). The basement is unconformably overlain by Permian to Lower Cretaceous cover sequences. During the Jurassic-Early Cretaceous, the two units were separated by the extended crust of the Fatric domain with its rift-related sediments [Plašienka, 1995b, 2003].

[9] The two realms were amalgamated during the northward progressing Eo-Alpine Cretaceous convergence. This event was responsible for the formation of far traveling cover nappes, thin-skinned tectonics in the northern frontal part of the accreted system and thick-skinned deformation in its rear southern part. The convergence led to the development of a crustal-scale nappe stack formed by the structurally highest Gemer, intermediate Vepor, and lowest Tatra Unit (Figure 1d) [Tomek, 1993; Plašienka et al., 1997]. The Alpine metamorphic overprint reached the highest P-T conditions in the Vepor Unit while intermediate to low-grade conditions are documented in the Gemer and Tatra units [Faryad, 1991; Janák et al., 2001; Danišik et al., 2010]. The associated closure of the Fatric basin led to the underthrusting of its basement (Figure 1d) and the northward detachment and nappe migration of its sedimentary infill (Krížna nappe in Figure 1c).

\subsection{Lithotectonic Structure of the Vepor Unit}

[10] For the purpose of this paper, we distinguish four intraVeporic domains (Figure 1c) characterized by distinct basement lithology, cover stratigraphy, basement/cover relationship, Cretaceous metamorphic and deformation record, and succession of individual deformation fabrics.

[11] The Northern Vepor Domain (Figure 1c) is represented by variably retrograded Variscan basement amphibolites, metapelites and granitoids and the anchimetamorphic clastics, shales and limestones of the parautochthonous Late PermianEarly Cretaceous northern Vepor cover (the Vel'ký Bok sequence [Biely, 1964]). The cover sequence is tectonically overlain by the Mesozoic Choč nappe [Plašienka, 1995a].

[12] The volumetrically most important Central Vepor Domain (Figure 1c) is dominated by Variscan crystalline basement with a complex Paleozoic history [Bezák et al., 1997]. The most prominent feature of the central Vepor basement is its inverted crustal structure indicated by the structurally lower medium-grade metapelite and amphibolite complex cropping out below the high-grade migmatite and granitoid complex [Klinec, 1966]. The metapelitic character of the whole deep Vepor is further corroborated by the interpretation of magnetic and gravity anomalies and reflection seismics [Bielik et al., 2004; Kubeš et al., 2010] as well as by xenoliths found within the tertiary andesites covering large parts of the Vepor Unit. This inverted crustal structure is typical for the Variscan basement of the northern realm Vepor and Tatra units and has been interpreted to result from Variscan nappe tectonics [Jacko et al., 1996; Bezák et al., 1997; Moussallam et al., 2012]. The migmatites and gneisses associated with synorogenic granitoids of Late Devonian age [Michalko et al., 1998] are intruded by large volumes of Late Carboniferous granitic and granodioritic magma [Bibikova et al., 1990]. The granitoids are overlain by the intensely deformed quartzite and arkose of the parautochthonous Permo-Triassic southern Vepor cover (Foederata sequence [Rozlozsnik, 1935]), the allochthonous Carboniferous-Permian sediments of Gemer affinity [Plašienka and Soták, 2001] and 

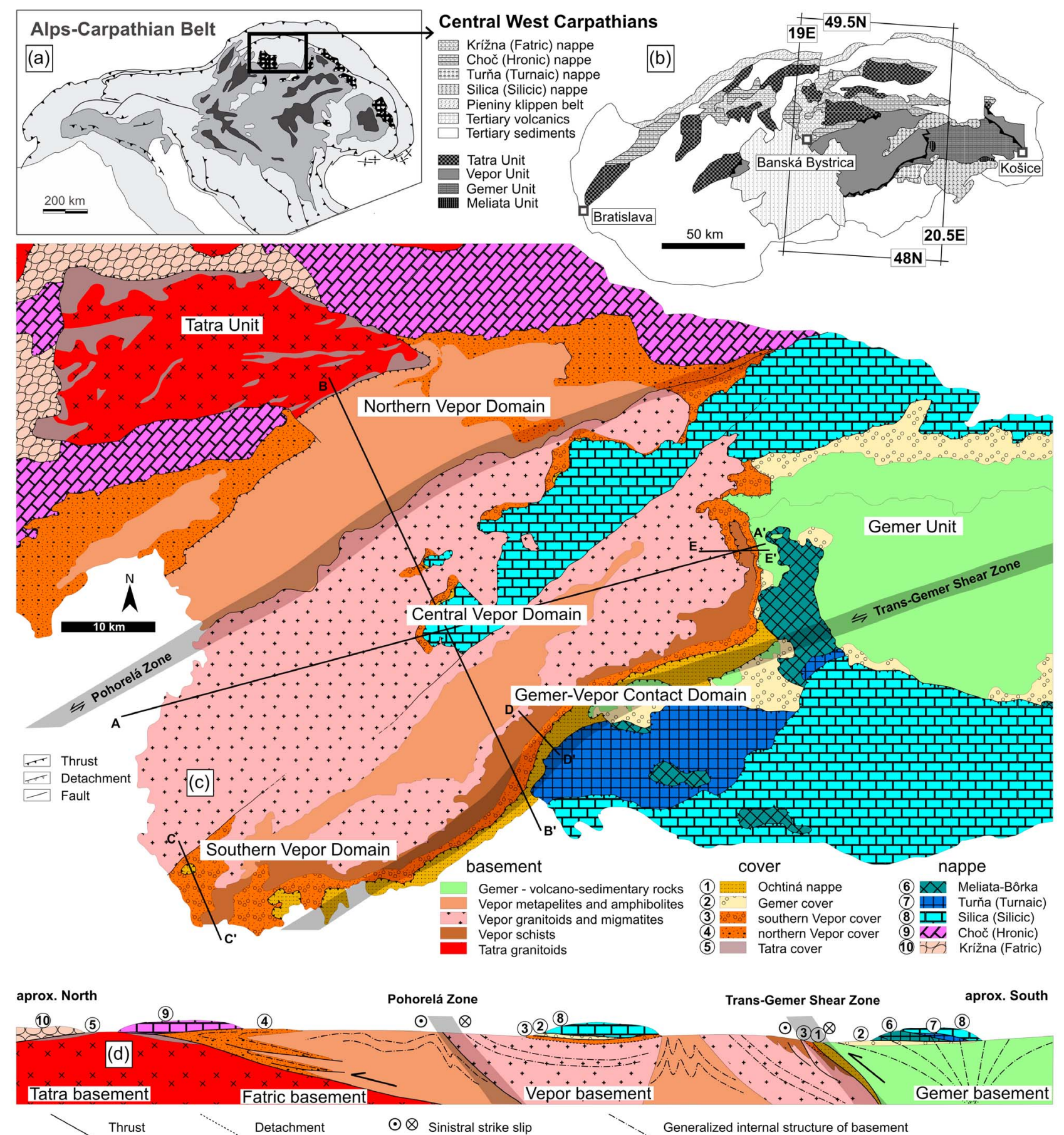

Figure 1. (a) Position of the Central West Carpathians in the Alpine-Carpathian belt. (b) Simplified tectonic map of the Central West Carpathians. (c) Lithotectonic map of the Vepor and surrounding units together with structural domains, main tectonic boundaries, and the position of structural cross sections shown in Figure 2. (d) Approximately N-S striking schematic geological cross section showing relative structural positions of the Tatra, Fatric, Vepor and Gemer basement, their cover sequences and overlying nappes.

the structurally highest weakly deformed Silica nappe (Figures 1c, 1d, 2a, and 2b).

[13] The Southern Vepor Domain is located at the southernmost exposed tip of the Vepor Unit (Figure 1c). The basement consists of Variscan amphibolites and metapelites which are locally intruded by granitoids. This domain has a uniquely autochthonous basement/cover relationship.
Here, the anchimetamorphic Permian-Triassic southern Vepor cover is represented by a conglomerate and arkose, quartzite, limestone, and dolomite sequence (Figure 2c). The cover is tectonically overlain by the dismembered Ochtiná nappe (Figures 1c and 2c) which is dominated by dark phyllites with lenses of basalt, amphibolite, serpentinite, magnesite and Visean to Namurian limestone [Kozur 

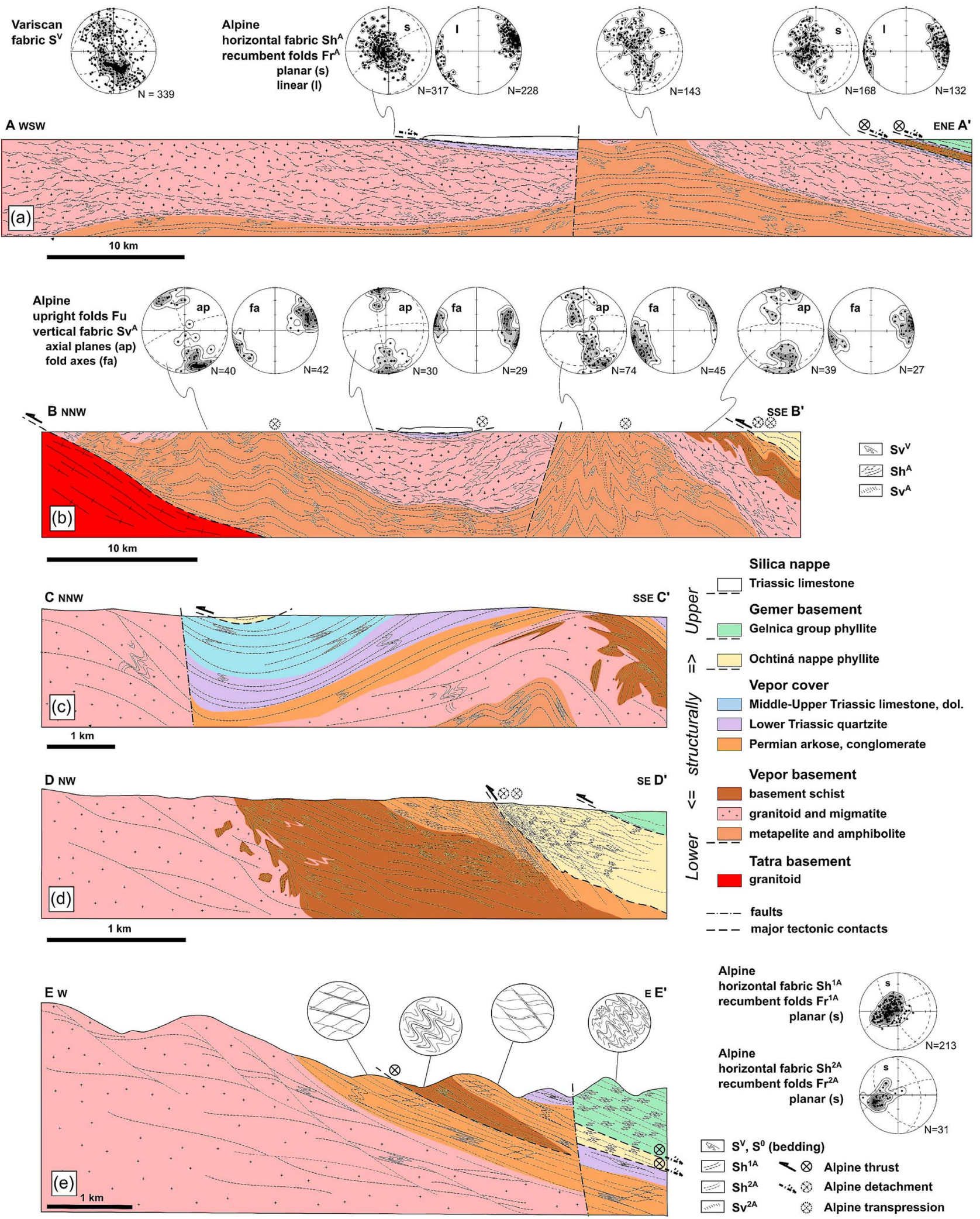

Figure 2. (a) Overview WSW-ENE structural profile $A-A^{\prime}$ and (b) NNW-SSE profile B-B' across the Vepor Unit, and (c) detailed NNW-SSE profile $\mathrm{C}-\mathrm{C}^{\prime}$ in the Southern Vepor Domain, (d) NW-SE profile D-D' in the Gemer-Vepor Contact Domain and (e) E-W profile E- $\mathrm{E}^{\prime}$ in the Central Domain and GemerVepor Contact Domain. Position of structural profiles is shown in Figure 1c. The presented pole figures of selected structures are in lower hemisphere equal-area Schmidt projection. Contours are double the multiples of standard deviation above the uniform distribution. 
et al., 1976]. Traditionally, the rocks of the Ochtiná nappe had been perceived as the Lower Carboniferous cover of the Gemer Unit. However, its structural position and heterogeneous lithological content advocate a separate evolution, possibly in the basin separating the Vepor and Gemer during Late Paleozoic-Mesozoic [e.g., Kozur and Mock, 1997].

[14] Toward the northeast, the Gemer-Vepor Contact Domain (Figure 1c) is characterized by extreme attenuation of both Vepor basement and cover. The basement consists of Variscan granitoids and schists intruded by leucogranite [Kamenický, 1977], which together with Permian arkose experienced severe deformation. The Ochtiná nappe is also extremely deformed, reduced to a thickness of several hundred meters, and fragmented and aligned parallel to the contact zone (Figures 1c and 1d). From the south, the contact zone is rimmed by the intensely sheared rocks of the Gemer Unit.

\section{Deformation Structures}

[15] Our tectonic model integrates several previously published papers on the Cretaceous convergence in the Central West Carpathians. These concentrated on deformation record in the Gemer Unit [Lexa et al., 2003], deformation record in the northern Vepor [Plašienka, 2003], and deformation microstructures and metamorphic record in the central Vepor [Jeřábek et al., 2007, 2008a]. In order to develop our model, some of the previous data need to be reviewed and/or extended. The new data presented in this paper comprise a detailed structural description of individual intraVeporic domains based on our robust data set of more than 5000 structural measurements documented at 1450 localities. Furthermore, our structural study is accompanied with detailed characterization of metamorphic record related to the individual deformation fabrics. This approach allows us to distinguish five separate tectonometamorphic stages of Cretaceous age with spatially complex overprinting relations. To clarify the superpositions of fabrics within each structural domain, we follow the notation method of Beltrando et al. [2008]. Although the notation looks complicated it is easy to read with the following system of abbreviations representing all possible combinations: $\mathrm{S}, \mathrm{h}, \mathrm{v}$, $\mathrm{F}, \mathrm{r}, \mathrm{u}_{\mathrm{am}, \mathrm{gr}}^{1,2 \mathrm{~V}, \mathrm{~A}}$ (S-planar fabric; h-horizontal; v-vertical; F-folds; r-recumbent; $\mathrm{u}$-upright; 1-first generation; 2-second generation; V-Variscan; A-Alpine; am-amphibolite; and gr-greenschist facies). The description of deformation sequence for each domain is provided in the following text. Structural maps showing spatial extent and intensity of individual Alpine fabrics as well as associated shear senses are shown in Figure 3.

\subsection{Structural Record in the Vepor Unit and Surrounding Domains}

\subsubsection{Fatric Domain}

[16] As the thinned Fatric basement has mostly vanished below the Vepor Unit, the structural information about the underthrusting process comes mainly from the Northern Vepor Domain [Plašienka, 1995a, 2003] and partially also from the detached sedimentary infill of the Fatric basin represented by the Krížna nappe. The Krížna nappe is an extensive thin allochthonous body which continuously overrides the Tatra Unit (Figure 1). The nappe shows rampflat partial overthrusts and development of folds and cleavages indicating its northward movement [Prokešová et al., 2012].

\subsubsection{Northern Vepor Domain}

[17] The structural pattern of the Northern Vepor Domain is dominated by south vergent basement and cover imbrications characterized by intercalations of basement thrust sheets and kilometer-scale cover recumbent folds with well-preserved overturned limbs [Plašienka, 2003]. This deformation is associated with lower greenschist facies phyllonites and mylonites heterogeneously reworking Variscan fabrics $\mathrm{S}_{\mathrm{am}}^{\mathrm{V}}$ in the basement (Figures $2 \mathrm{~b}$ and 3 ). The accompanying asymmetric and recumbent folding $\mathrm{Fr}_{\mathrm{gr}}^{1 \mathrm{~A}}$ (Figure 4a) is associated with the development of a gently south dipping axial planar cleavage $\mathrm{Sh}_{\mathrm{gr}}^{1 \mathrm{~A}}$ and strong $\mathrm{E}-\mathrm{W}$ trending intersection lineation. In the east of this domain, along the N-S striking basement-cover contact (Figure 1c), the $\mathrm{Sh}_{\mathrm{gr}}^{1 \mathrm{~A}}$ fabric is locally overprinted by a discrete subhorizontal or gently east dipping fabric $\mathrm{Sh}_{\mathrm{gr}}^{2 \mathrm{~A}}$ indicating consistent top-to-the-east shear sense (Figure 3). The whole package of sheared basement and recumbent cover folds is folded by late upright $\mathrm{E}-\mathrm{W}$ trending folds $\mathrm{Fu}_{\mathrm{gr}}^{2 \mathrm{~A}}$ of various scales. The southern boundary of the Northern Vepor Domain is delineated by a sinistral transpressive zone up to two kilometers in width and trending NE-SW (the Pohorelá zone [Putǐ̌, 1991; Madarás et al., 1994]). This zone is characterized by an increase in Alpine metamorphic grade and coincides with a large-scale antiform cored by metapelites and amphibolites [Jeřábek et al., 2008a]. Similarly to the Central Vepor Domain characterized by identical antiformal structure (Figure $2 b$ ), this relatively narrow zone exhibits the development of steep NE-SW trending lower greenschist facies cleavages $\mathrm{Sv}_{\mathrm{gr}}^{2 \mathrm{~A}}$. The documented sequence of deformation events in the Northern Vepor Domain can be expressed by the following deformation sequence diagram:

$$
\mathrm{S}_{\mathrm{am}}^{\mathrm{V}} / \mathrm{S}^{0}, \mathrm{Fr}_{\mathrm{gr}}^{1 \mathrm{~A}}=>\mathrm{Sh}_{\mathrm{gr}}^{1 \mathrm{~A}}, \mathrm{Sh}_{\mathrm{gr}}^{2 \mathrm{~A}}, \mathrm{Fu}_{\mathrm{gr}}^{2 \mathrm{~A}}=>\mathrm{Sv}_{\mathrm{gr}}^{2 \mathrm{~A}}
$$

\subsubsection{Central Vepor Domain}

[18] The Central Vepor Domain is characterized by contrasting deformation sequences in the basement lower metapelite and amphibolite complex and upper granitoid and migmatite complex (Figure 1d). The volumetrically more important upper granitoid and migmatite complex reveals systematic E-W variations in structural style and deformation intensity (Figures $2 \mathrm{a}$ and 3 ). The westernmost portion of this complex is virtually unaffected by Alpine tectonics. It is dominated by steep north dipping Variscan fabrics $\mathrm{S}_{\mathrm{am}}^{\mathrm{V}}$ represented by migmatitic layering (Figure 5a), high-

Figure 3. Structural maps of individual Alpine fabrics showing trajectories and dips of metamorphic foliations and cleavages and associated lineation or fold axes. The background gray scale manifests spatial extent and intensity of individual deformation events. Major thrusts and detachments together with shear sense for individual fabrics are also indicated. The red line delimits an extent of granitoid and migmatite lithological complex. 


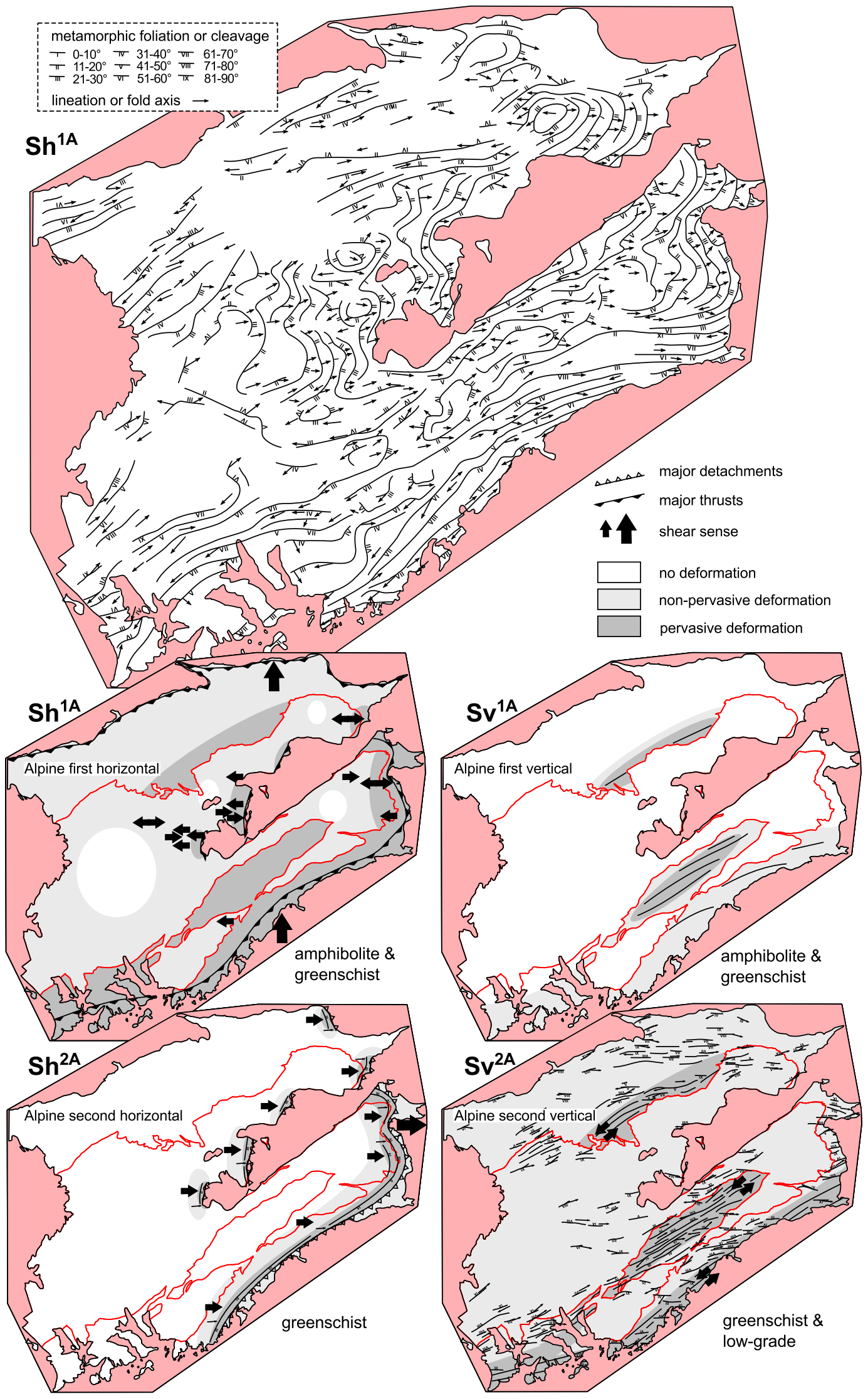

Figure 3

6 of 26 

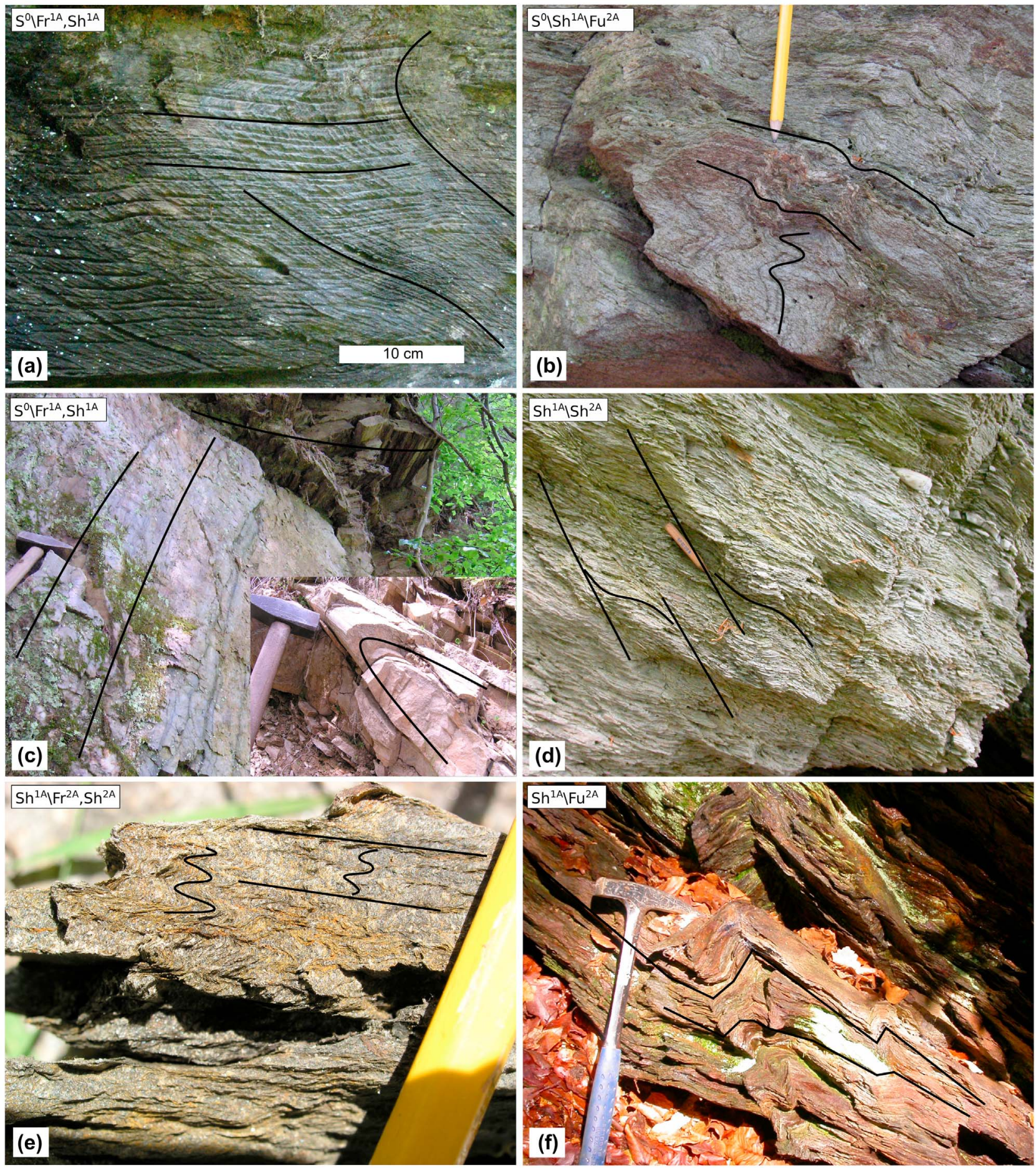

Figure 4. Field photographs of selected structures in the cover: (a) closed to isoclinal folds $\mathrm{Fr}^{1 \mathrm{~A}}$ of sedimentary layering $S^{0}$ and development of axial planar cleavage $S^{1 A}$ in limestone of the northern Vepor cover in the Northern Vepor Domain, (b) folded sedimentary layering $S^{0}$ by the $\mathrm{Fr}^{1 \mathrm{~A}}$ folds and development of axial planar cleavage $\mathrm{Sh}^{1 \mathrm{~A}}$ that is folded by upright folds $\mathrm{Fu}^{2 \mathrm{~A}}$ in quartzitic schist of the GemerVepor Contact Domain, (c) sedimentary layering $\mathrm{S}^{0}$ affected by the $\mathrm{Fr}^{1 \mathrm{~A}}$ folds and the development of axial planar cleavage $\mathrm{Sh}^{1 \mathrm{~A}}$ in quartzite of the Gemer-Vepor Contact Domain, (d) apparent $\mathrm{C} / \mathrm{S}$ fabrics formed by $\mathrm{Sh}^{2 \mathrm{~A}} / \mathrm{Sh}^{1 \mathrm{~A}}$ superposition in quartzite of the Central Vepor Domain, (e) isoclinal folds $\mathrm{Fr}^{2 \mathrm{~A}}$ affecting steepened $\mathrm{Sh}^{1 \mathrm{~A}}$ schistosity and development of $\mathrm{Sh}^{2 \mathrm{~A}}$ in the Ochtiná nappe phyllite of the Gemer-Vepor Contact Domain, (f) upright kink bands $\mathrm{Fu}^{2 \mathrm{~A}}$ affecting fabric $\mathrm{Sh}^{1 \mathrm{~A}}$ in schists of the Gemer-Vepor Contact Domain. 

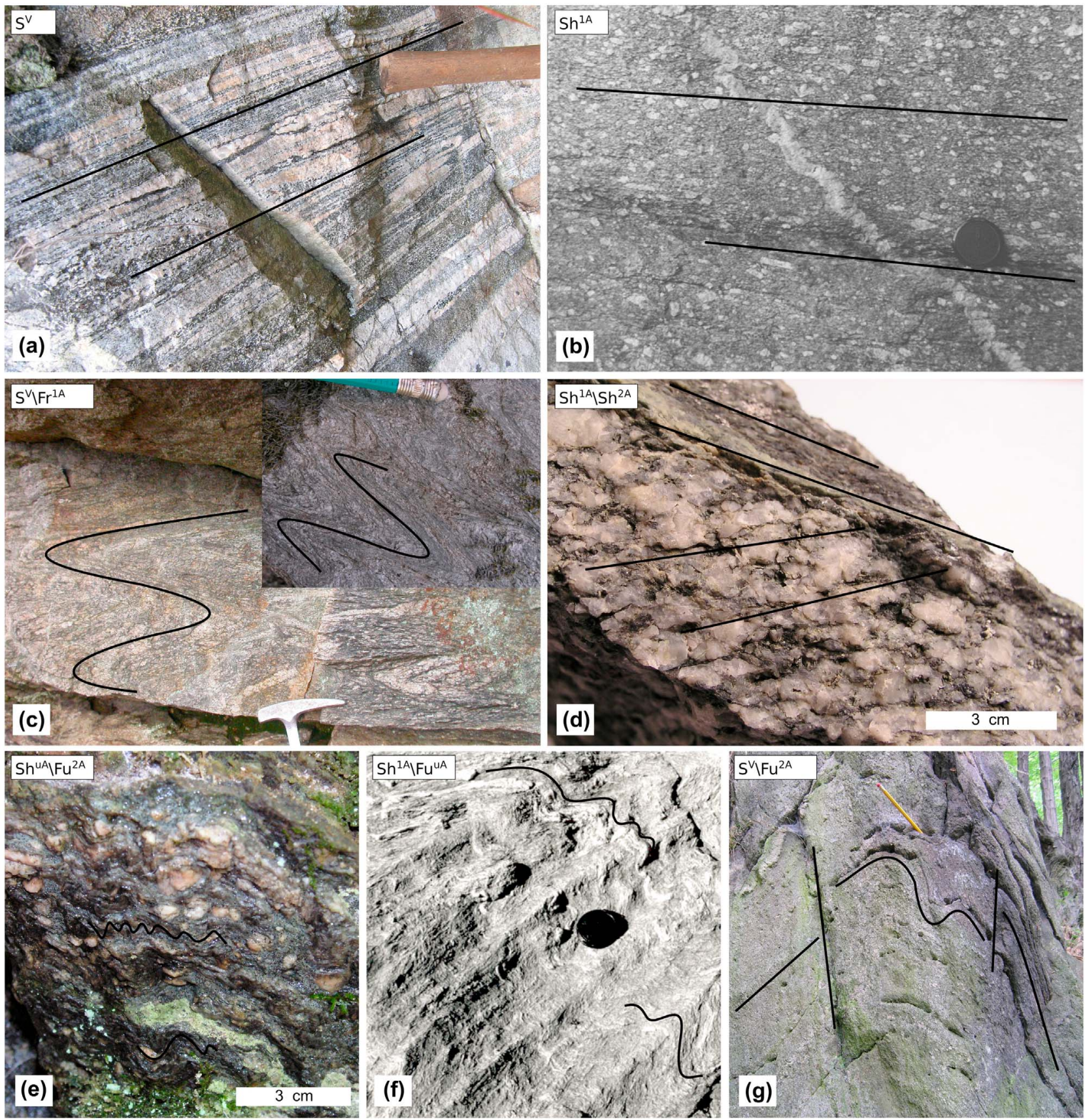

Figure 5. Field photographs of selected structures in the basement: (a) Variscan migmatite layering $S^{\mathrm{V}}$ in amphibolite of the Central Vepor Domain, (b) mylonitic fabric $\mathrm{Sh}^{1 \mathrm{~A}}$ in orthogneiss of the Central Vepor Domain, (c) isoclinal recumbent folds $\mathrm{Fr}^{1 \mathrm{~A}}$ of Variscan fabric $\mathrm{S}^{\mathrm{V}}$ in orthogneiss of the Central Vepor Domain, (d) detachment fabric $\mathrm{Sh}^{2 \mathrm{~A}}$ overprinting an earlier fabric $\mathrm{Sh}^{1 \mathrm{~A}}$ in orthogneiss of the Central Vepor Domain, (e) crenulations $\mathrm{Fu}^{2 \mathrm{~A}}$ affecting undifferentiated composite mylonitic fabric $\mathrm{Sh}^{\mathrm{uA}}\left(\mathrm{Sh}^{1 \mathrm{~A}}\right.$ and/or $\left.\mathrm{Sh}^{2 \mathrm{~A}}\right)$ in orthogneiss of the Central Vepor Domain, (f) undifferentiated upright folds $\mathrm{Fu}^{\mathrm{uA}}\left(\mathrm{Fu}^{1 \mathrm{~A}}\right.$ and/or Fu$\left.{ }^{2 \mathrm{~A}}\right)$ affecting schistosity $\mathrm{Sh}^{1 \mathrm{~A}}$ in mica schist of the Central Vepor Domain, (g) upright folds $\mathrm{Fu}^{2 \mathrm{~A}}$ affecting Variscan migmatitic layering $\mathrm{S}^{\mathrm{V}}$ in the Southern Vepor Domain.

grade gneissosity and magmatic fabrics in granitoids. Toward the east, the granitoids are affected by an array of flat east or west dipping anastomosing shear zones $\mathrm{Sh}_{\mathrm{am}}^{1 \mathrm{~A}}$ which occupy a $4-5 \mathrm{~km}$ wide $\mathrm{N}-\mathrm{S}$ trending zone (Figure 3 ). Further to the east near the basement-cover contact, the whole region is pervasively deformed forming a $6 \mathrm{~km}$ wide zone of subhorizontally to gently east dipping $\mathrm{Sh}_{\mathrm{am}}^{1 \mathrm{~A}}$ orthogneiss mylonites (Figures 3 and $5 b$ ). Identical deformation zoning occurs repeatedly in the vicinity of N-S striking basement-cover contacts across the granitoid and migmatite complex (Figure 3). The $\mathrm{Sh}_{\mathrm{am}}^{1 \mathrm{~A}}$ fabric is axial planar to locally preserved isoclinal folds $\mathrm{Fr}_{\mathrm{am}}^{\mathrm{AA}}$ affecting the Variscan 
metamorphic and magmatic fabrics $\mathrm{S}_{\mathrm{am}}^{\mathrm{V}}$ in the basement and bedding $\mathrm{S}^{0}$ in the overlying cover (Figures $4 \mathrm{~b}, 4 \mathrm{c}$, and $5 \mathrm{c}$ ). The axes of these folds are subparallel to mineral and stretching lineation (Figures 2a and 3) defined by shape preferred orientation of micas and recrystallized quartz aggregates. The stretching lineation is characterized by conflicting sense of shear criteria [Jerábek et al., 2007]. The flat mylonitic foliation $\mathrm{Sh}_{\mathrm{am}}^{1 \mathrm{~A}}$ is heterogeneously overprinted by gently east dipping discrete shear zones $\mathrm{Sh}_{\mathrm{gr}}^{2 \mathrm{~A}}$ (Figures $2 \mathrm{e}$ and $5 \mathrm{~d}$ ). These shear zones bear an east plunging muscovite and quartz aggregate lineation and show systematic top-to-the-east sense of shear (Figure 3). This deformation culminates at the basement-cover boundary (Figure 2e) where the $\mathrm{Sh}_{\mathrm{gr}}^{2 \mathrm{~A}}$ is associated with a zone of basement and cover mylonites and ultramylonites of up to hundred meters in width. These are rich in shear sense criteria such as apparent $\mathrm{C} / \mathrm{S}$ fabrics formed by superposed $\mathrm{Sh}_{\mathrm{gr}}^{2 \mathrm{~A}} / \mathrm{Sh}_{\mathrm{am}}^{1 \mathrm{~A}}$ (Figure 4d), sigmoidal clasts, rotated veins and mineral fabrics [Hók et al., 1993; Plašienka, 1993; Putiš et al., 1997b; Bukovská et al., 2012]. This zone has been identified by the above mentioned authors as a major extensional detachment (Figure 3) and the highly deformed relics of the cover sequence as extensional allochthons. Both $\mathrm{Sh}_{\mathrm{am}}^{1 \mathrm{~A}}$ and $\mathrm{Sh}_{\mathrm{gr}}^{2 \mathrm{~A}}$ flat fabrics in orthogneiss are affected by small-scale folding $\mathrm{Fu}_{\mathrm{gr}}^{2 \mathrm{~A}}$ (Figures $4 \mathrm{~b}$ and $5 \mathrm{e}$ ).

[19] Structural analysis of the lower metapelite and amphibolite complex revealed complete transposition of the steep $\mathrm{E}-\mathrm{W}$ trending Variscan fabric $\mathrm{S}_{\mathrm{am}}^{\mathrm{V}}$ by subhorizontal foliation $\mathrm{Sh}_{\mathrm{am}}^{1 \mathrm{~A}}$. Similarly to the northern Vepor, the lower metapelite and amphibolite complex emerges through the upper granitoid and migmatite complex within the core of a large-scale antiform (Figures $2 b$ and 3 ). The initial stages of development of this antiform are associated with upright folding $\mathrm{Fu}_{\mathrm{am}}^{1 \mathrm{~A}}$ of the subhorizontal $\mathrm{Sh}_{\mathrm{am}}^{1 \mathrm{~A}}$ fabric and the development of lower amphibolite facies vertical cleavage $\mathrm{Sv}_{\mathrm{am}}^{1 \mathrm{~A}}$. Subsequent reactivation of the $\mathrm{Sv}_{\mathrm{am}}^{1 \mathrm{~A}}$ and tightening of the $\mathrm{Fu}_{\mathrm{am}}^{1 \mathrm{~A}}$ by a discrete retrograde $\mathrm{Svgr}_{\mathrm{gr}}^{2 \mathrm{~A}}$ cleavage and $\mathrm{Fu}_{\mathrm{gr}}^{2 \mathrm{~A}}$ folds mostly obliterated the first generation of structures and lead to further amplification of the large-scale antiform. The later folding phase reveals a progressive counterclockwise rotation of fold hinges from E-W toward NE-SW orientations indicating the transpressional character of this late folding event [e.g., Lexa et al., 2003]. Vast domain between the northern and central domain antiforms is occupied by a gentle synform coring the southern Vepor cover and Silica nappe (Figures 1c and 2b). The small-scale upright folds within these large-scale structures are $\mathrm{E}-\mathrm{W}$ striking in the upper granitoid and migmatite complex and mostly ENEWSW to NE-SW striking in the lower metapelite and amphibolite complex (Figures $2 \mathrm{~b}$ and 3 ). Such a fold axes pattern stems from the late transpressional partitioning of deformation. The deformation within the upper granitoid and migmatite complex and overlying southern Vepor cover may be characterized by the following deformation sequence:

$$
\mathrm{S}_{\mathrm{am}}^{\mathrm{V}} / \mathrm{S}^{0}, \mathrm{Fr}_{\mathrm{am}}^{1 \mathrm{~A}}=>\mathrm{Sh}_{\mathrm{am}}^{1 \mathrm{~A}}, \mathrm{Sh}_{\mathrm{gr}}^{2 \mathrm{~A}}, \mathrm{Fu}_{\mathrm{gr}}^{2 \mathrm{~A}}=>\mathrm{Sv}_{\mathrm{gr}}^{2 \mathrm{~A}}
$$

In contrast the sequence of events within the lower metapelite and amphibolite complex can be expressed as follows:

$$
\mathrm{S}_{\mathrm{am}}^{\mathrm{V}}, \mathrm{Fr}_{\mathrm{am}}^{1 \mathrm{~A}}=>\mathrm{Sh}_{\mathrm{am}}^{1 \mathrm{~A}}, \mathrm{Fu}_{\mathrm{am}}^{1 \mathrm{~A}}=>\mathrm{Sv}_{\mathrm{am}}^{1 \mathrm{~A}}, \mathrm{Fu}_{\mathrm{gr}}^{2 \mathrm{~A}}=>\mathrm{Sv}_{\mathrm{gr}}^{2 \mathrm{~A}}
$$

\subsubsection{Southern Vepor Domain}

[20] The basement of the Southern Vepor Domain is dominated by steep to flat Variscan migmatitic layering and high-grade gneissosity $\mathrm{S}_{\mathrm{am}}^{\mathrm{V}}$ (Figure 2c). The basement is unconformably covered by the weakly metamorphosed southern Vepor cover sequence [Lupták et al., 2003]. The greenschist facies Alpine deformation fabric $\mathrm{Sh}_{\mathrm{gr}}^{1 \mathrm{~A}}$ overprints the migmatitic layering $\mathrm{S}_{\mathrm{am}}^{\mathrm{V}}$ which is locally converted to zones of flat-lying phyllonites while the isotropic granite is affected by a heterogeneous array of shear zones (Figure 3). The rocks of Mesozoic cover reveal a bedding parallel metamorphic schistosity $\mathrm{Sh}_{\mathrm{gr}}^{1 \mathrm{~A}}$ sometimes associated with development of isoclinal folds $\mathrm{Fr}_{\mathrm{gr}}^{1 \mathrm{~A}}$ in marbles. The whole package of basement and cover rocks is affected by small- to large-scale folding $\mathrm{Fu}_{\mathrm{gr}}^{2 \mathrm{~A}}$ affecting both Variscan (Figure $5 \mathrm{~g}$ ) and Alpine metamorphic fabrics. The cover sequence is preserved in the core of a kilometer-scale $\mathrm{Fu}_{\mathrm{gr}}^{2 \mathrm{~A}}$ synform (Figures $2 \mathrm{c}$ and 3). Steep NE-SW trending zones with cleavage $\mathrm{Sv}_{\mathrm{gr}}^{2 \mathrm{~A}}$ locally develop in the basement. The sequence of deformation in the southern domain can be expressed as follows:

$$
\mathrm{S}_{\mathrm{am}}^{\mathrm{V}} / \mathrm{S}^{0}, \mathrm{Fr}_{\mathrm{am}}^{1 \mathrm{~A}}=>\mathrm{Sh}_{\mathrm{am}}^{1 \mathrm{~A}}, \mathrm{Fu}_{\mathrm{gr}}^{2 \mathrm{~A}}=>\mathrm{Sv}_{\mathrm{gr}}^{2 \mathrm{~A}}
$$

\subsubsection{Gemer-Vepor Contact Domain}

[21] This zone of prominent deformation and attenuation can be divided into two parts, the N-S striking eastern part and NE-SW striking southeastern part (Figures 1c and 3). In basement schists, the locally preserved south dipping Variscan fabrics $\mathrm{S}_{\mathrm{am}}^{\mathrm{V}}$ are reworked by recumbent folds $\mathrm{Fr}_{\mathrm{am}}^{\mathrm{1A}}$ and amphibolite facies schistosity $\mathrm{Sh}_{\mathrm{am}}^{1 \mathrm{~A}}$ (Figure 2d). In the Vepor cover and Ochtiná nappe, the asymmetric to isoclinal recumbent folds $\operatorname{Fr}_{\mathrm{gr}}^{1 \mathrm{~A}}$ and axial planar greenschist metamorphic schistosity $\operatorname{Sh}_{\mathrm{gr}}^{1 \mathrm{~A}}$ (Figures $4 \mathrm{~b}$ and $4 \mathrm{c}$ ) affected the previously steepened bedding $\mathrm{S}^{0}$. Recumbent folding of the locally steepened basement-cover interface led to development of a complex structure manifested by the basement schists overlying Permian quartzite in the eastern part of the Gemer-Vepor Contact Domain (Figure 2e).

[22] The $\mathrm{Sh}_{\mathrm{am}-\mathrm{gr}}^{1 \mathrm{~A}}$ schistosity in the basement and cover was subsequently heterogeneously overprinted by the east dipping detachment fabric $\mathrm{Sh}_{\mathrm{gr}}^{2 \mathrm{~A}}$ developed mainly in the eastern part of the contact domain (Figure 3) [Hók et al., 1993; Plašienka, 1993; Bukovská et al., 2012]. The recumbent folds $\mathrm{Fr}_{\mathrm{gr}}^{2 \mathrm{~A}}$ are rare in the basement and more frequent in the Veporic cover and Ochtiná nappe (Figure 4e). This advocates a more pronounced steepening of the $\mathrm{Sh}^{1 \mathrm{~A}}$ fabrics toward the external parts of the Vepor Dome resulting from previous $\mathrm{Fu}^{1 \mathrm{~A}}$ folding. Furthermore, the overall doming of the Vepor Unit prior to development of the detachment fabric $\mathrm{Sh}_{\mathrm{gr}}^{2 \mathrm{~A}}$ is suggested by the circular organization of $\mathrm{Fr}_{\mathrm{gr}}^{2 \mathrm{~A}}$ fold axes. These show generally E-W trends in the southeastern part of the contact domain and generally $\mathrm{N}-\mathrm{S}$ trends in its eastern part. The hanging wall Gemer basement to the east also shows overprint of an undifferentiated steep E-W trending fabric by recumbent folds $\mathrm{Fr}_{\mathrm{gr}}^{2 \mathrm{~A}}$ and associated very low grade cleavage $\mathrm{Sh}^{2 \mathrm{~A}}$. Subsequent postdetachment upright folding $\mathrm{Fu}_{\mathrm{gr}}^{2 \mathrm{~A}}$ is manifested by steepening of both subhorizontal $\mathrm{Sh}^{1 \mathrm{~A}^{2}}$ and $\mathrm{Sh}^{2 \mathrm{~A}}$ fabrics (Figure 3) within the limbs of large-scale folds. This folding is accompanied with the development of $\mathrm{E}-\mathrm{W}$ trending crenulation cleavage in 
the eastern part of the contact domain and NE-SW trending kink bands, small-scale folds and discrete steep cleavage $\mathrm{Sv}_{\mathrm{gr}}^{2 \mathrm{~A}}$ in its southeastern part (Figures $4 \mathrm{~b}$ and $4 \mathrm{f}$ ). In the Ochtiná nappe, the $\mathrm{Sv}_{\mathrm{gr}}^{2 \mathrm{~A}}$ cleavage completely transposes all previous fabrics. The southeastern contact between the Vepor and Gemer units is affected by development of a late stage transpressive shear zone (Figures $2 \mathrm{~d}$ and 3 ) extending eastward to the interior of the Gemer Unit (the Trans-Gemer Shear Zone in Figure 1c). The Gemer-Vepor Contact Domain is the only domain recording the complete sequence of deformation events in the Vepor Unit expressed by the following deformation sequence diagram:

$$
\mathrm{S}_{\mathrm{am}}^{\mathrm{V}} / \mathrm{S}^{0}, \mathrm{Fr}_{\mathrm{am}}^{1 \mathrm{~A}}=>\mathrm{Sh}_{\mathrm{am}}^{1 \mathrm{~A}}, \mathrm{Fu}_{\mathrm{gr}}^{1 \mathrm{~A}}, \mathrm{Fr}_{\mathrm{gr}}^{2 \mathrm{~A}}=>\mathrm{Sh}_{\mathrm{gr}}^{2 \mathrm{~A}}, \mathrm{Fu}_{\mathrm{gr}}^{2 \mathrm{~A}}=>\mathrm{Sv}_{\mathrm{gr}}^{2 \mathrm{~A}}
$$

\subsubsection{Gemer Domain}

[23] Several deformation fabrics have been identified throughout the Gemer basement and its Late Paleozoic cover. Variscan metamorphic foliation in the Gemer basement dips generally to the NNW at shallow to intermediate angles and its metamorphic grade decreases from amphibolite facies in the north to greenschist facies in the south. The Gemer Unit is dominated by two prominent deformation structures of Cretaceous age: the Gemer Cleavage Fan and the Trans-Gemer Shear Zone [Lexa et al., 2003]. The Gemer Cleavage Fan is represented by $\mathrm{E}-\mathrm{W}$ striking cleavages forming a large-scale asymmetric positive fan structure (Figure 1d). The cleavage intensity, dip angle and metamorphic grade decreases from the axial zone toward north and south. The Trans-Gemer Shear Zone is characterized by development of a several kilometer wide zone of steep NESW to ENE-WSW trending cleavages (Figure 1c and 1d). Subhorizontal lineation together with numerous shear sense and offset indicators along this zone indicate its sinistral transcurrent movement [Lexa et al., 2003].

\subsection{Finite Strain Pattern, Stretching Lineation and Shear Sense Criteria}

[24] The above described structural record documents that finite strain pattern in the Vepor Unit results from multiple superpositions of subvertical E-W trending and subhorizontal fabrics. As a consequence, the finite strain pattern throughout the Vepor Unit is dominated by subhorizontal E$\mathrm{W}$ trending intersections. It has been shown that the $\mathrm{Sh}^{1 \mathrm{~A}}$ fabric represents the most extensive and intense deformation phase of Cretaceous age in the Vepor Unit. In contrast, the subsequent phases are less intense and/or spatially restricted into mechanically weaker lithological complexes (Figure 3). The $\mathrm{Sh}^{1 \mathrm{~A}}$ fabric is best preserved in the mechanically stronger granitoid and migmatite complex of the central Vepor which makes it the most suitable candidate to study relative contribution of individual deformation fabrics to the finite strain pattern.

[25] The finite strain data were obtained by evaluating shape preferred orientation (SPO) of recrystallized quartz aggregates defining the $\mathrm{Sh}^{1 \mathrm{~A}}$ fabric (Figure 6a). The aggregates represent the weakest phase in weakly gneissified granites and relatively strong phase in intensely sheared gneisses (Figure 5b) (for details, see Jeřábek et al. [2007]). This data set has been complemented with recalculated AMS (Anisotropy of Magnetic Susceptibility) data from both weakly and highly deformed granites [Hrouda et al., 2002].
These authors concluded that the AMS was carried by the paramagnetic fraction represented by biotite. Therefore, the AMS data can be recalculated to Scheidegger orientation tensor [Scheidegger, 1965] and subsequently to finite strain ellipsoid using the SUSIE software of Ježek and Hrouda [2007]. It is assumed that biotite together with muscovite represent the weakest mineral fraction accommodating deformation in granitoids. Therefore, the preferred orientation of biotite quantified using the orientation tensor [Hrouda and Schulmann, 1990] provides a good proxy of the finite strain ellipsoid in deformed gneisses. This assumption is further corroborated by similar results obtained by the two independent methods at places where their application overlaps (see Figures $6 \mathrm{~b}$ and $6 \mathrm{c}$ ).

[26] The absolute values of deformation intensity (Figure 6b) obtained from quartz aggregates are biased by an effect of strain partitioning between stronger quartz and weaker matrix. For this reason, we only discuss the shapes of finite strain ellipsoids (strain symmetry) presented in a finite strain map (Figure 6c). In general, the finite strains are characterized by prolate ellipsoids in the areas of overall low deformation intensity characterized by the development of anastomosing shear zones $\mathrm{Sh}^{1 \mathrm{~A}}$ and by oblate ellipsoids in the areas of homogeneous and pervasive $\mathrm{Sh}^{1 \mathrm{~A}}$ mylonitization (cf. Figures 3 and $6 \mathrm{c}$ ). The gradual transition from prolate to oblate deformation is marked by a narrow zone of plane strain. As a complementary study, an internal fabric within the quartz aggregates has been evaluated (Figure 7). The shape analyses of recrystallized quartz grains show that in the XZ sections of finite strain ellipsoid, the internal grain SPO is mostly subparallel to the external macroscopic foliation, while in the YZ sections the angle between internal and external fabrics varies significantly. The combined results of aggregate and grain shape analyses indicate that the prolate aggregates are characterized by subparallel orientation of the grain SPO and external macroscopic foliation (Figure 7a). In contrast, the oblate aggregates revealed a high angular relationship between the grain SPO and external macroscopic foliation resulting from an overprint by subsequent $\mathrm{Fu} / \mathrm{Sv}$ deformation (Figure 7b). The angle between aggregate and grain SPO generally increases toward the easterly $\mathrm{Sh}^{2 \mathrm{~A}}$ detachments (Figure 7c).

[27] The study of a crystal preferred orientation of recrystallized quartz within the aggregates confirmed their E-W stretching associated with development of the $\mathrm{Sh}^{1 \mathrm{~A}}$ fabric [Jeŕábek et al., 2007]. On the other hand, the observed crossed and single girdle quartz crystal preferred orientation patterns typical for plane strain deformation [Lister and Hobbs, 1980; Schmid and Casey, 1986] contrast with the oblate and prolate shapes of aggregates. This suggests that the differences in finite strain symmetry of the $\mathrm{Sh}^{1 \mathrm{~A}}$ fabric probably result from an overprint of variously inclined $\mathrm{S}^{\mathrm{V}}$ fabric. In addition, the quartz fabric shear sense criteria characterized by conflicting sense of shear [Jeŕábek et al., 2007] point to a dominantly coaxial flow (Figures 8a and 8b) during the formation of $\mathrm{Sh}^{1 \mathrm{~A}}$.

\section{Relationship Between Metamorphism and Deformation}

\section{1. $S_{a m}^{V}$ Fabric}

[28] In our concept, the Variscan $\mathrm{S}_{\mathrm{am}}^{\mathrm{V}}$ metamorphic fabric (Figures 5a and 5c) covers several generations of deformation/magmatic fabrics of Variscan age. From the Alpine 


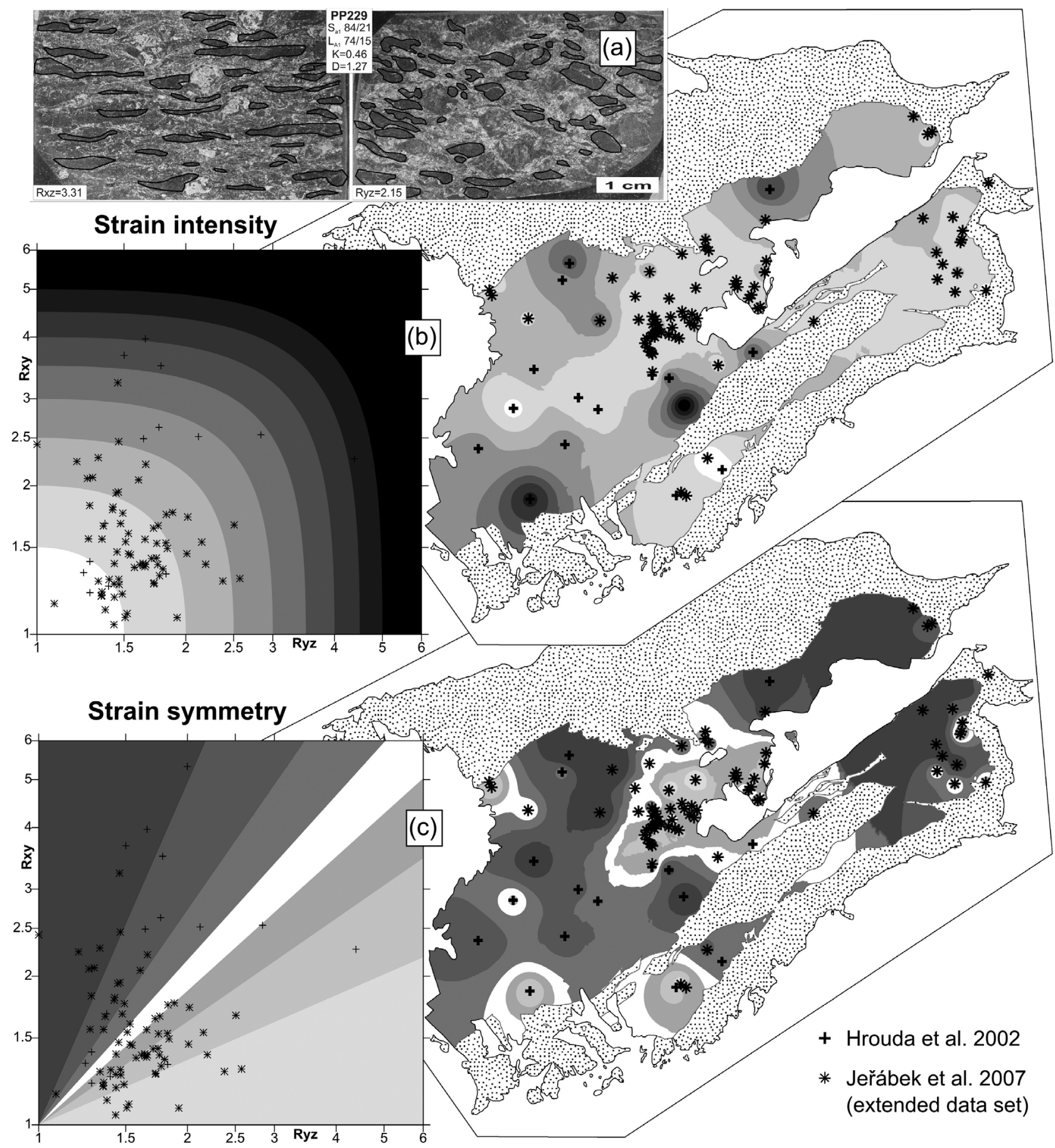

Figure 6. (a) Results of strain analysis covering the $\mathrm{Sh}^{1 \mathrm{~A}}$ fabric in the Vepor orthogneiss are based on shape analysis of recrystallized quartz aggregates [Jeŕábek et al., 2007] and anisotropy of magnetic susceptibility [Hrouda et al., 2002]. The (b) intensity and (c) symmetry of deformation [Ramsay, 1967] are shown in the Flinn diagram and map. The spatial grid was calculated using the IDW interpolation method in the ArcGis software. The gray scale scheme in the grids corresponds to gray scale in the Flinn diagrams to the left.

fabrics, they are distinguished by their higher temperature metamorphic mineral assemblage and microstructural relations. In the northern domain, the Variscan fabrics are associated with hornblende bearing amphibolites and retrogressed eclogites [Janák et al., 2007]. The Variscan fabrics $\mathrm{S}^{\mathrm{V}}$ in metapelites are characterized by syntectonic growth of garnet, kyanite and staurolite described by Putiš et al. [1997a] and Jeŕábek et al. [2008b] from the northern domain, and Méres and Hovorka [1991] and Kováčik et al. [1996] from the central domain. In the schists of the Gemer-Vepor Contact Domain, the Variscan mineral assemblage consists of garnet, biotite, muscovite and plagioclase and it is poorly preserved 

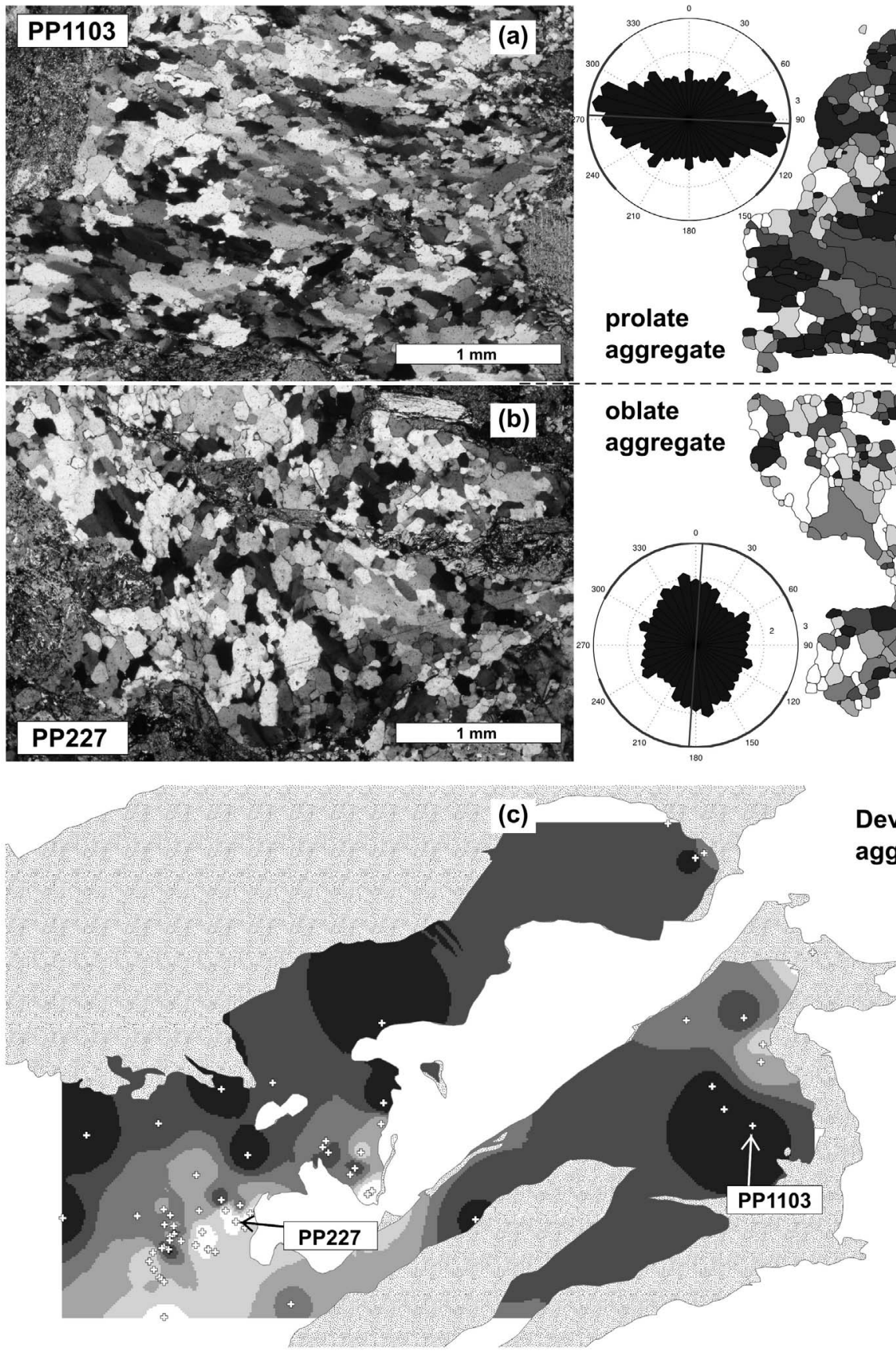
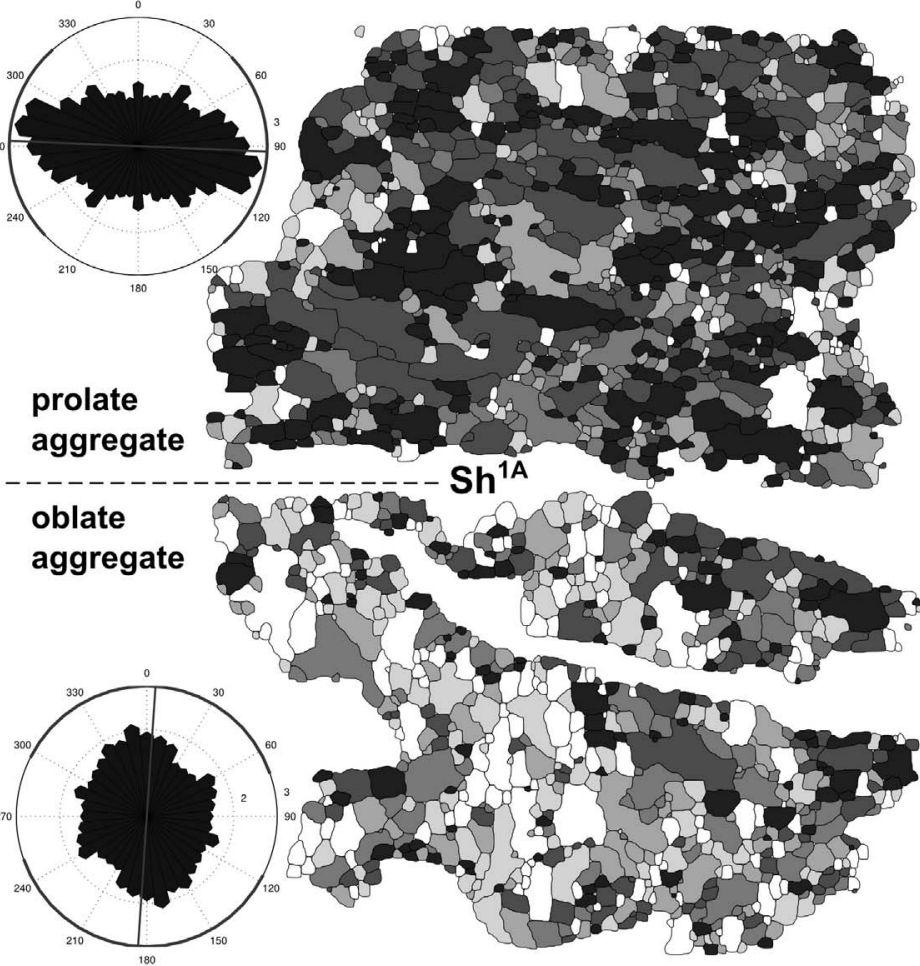

Deviation angle between aggregate SPO $\left(\mathrm{Sh}^{1 \mathrm{~A}}\right)$ and grain SPO

Figure 7. An example of recrystallized quartz grain shape preferred orientation in YZ section of finite strain ellipsoid related to $\mathrm{Sh}^{1 \mathrm{~A}}$ fabric in (a) prolate sample PP1103 showing subparallel grain and aggregate shape preferred orientations (SPOs) and (b) oblate sample PP227 showing perpendicular grain and aggregate SPOs. The rose diagrams show mean orientation of the grain long axes. (c) The grid calculated by using the IDW interpolation method in ArcGis software shows the regional distribution of angular deviation between the grain and aggregate $\mathrm{SPO}\left(\mathrm{Sh}^{1 \mathrm{~A}}\right.$ fabric).

due to an intense Cretaceous overprint. The granitoid and migmatite complex shows magmatic, anatectic and migmatitic fabrics $\mathrm{S}_{\mathrm{am}}^{\mathrm{V}}$, which contain garnet, biotite, muscovite, $\mathrm{K}$ feldspar and plagioclase.

[29] The Variscan assemblages in metapelites show similar P-T conditions of $0.8 \mathrm{GPa}$ at $650^{\circ} \mathrm{C}$ in both northern and central domain [Putiš et al., 1997a; Jeřábek et al., 2008a]. The eclogite boudins preserved in the northern Vepor reveal peak P-T conditions of $2.5 \mathrm{GPa}$ at $700^{\circ} \mathrm{C}$ [Janák et al., 2007] and Variscan retrogression at $1-1.2 \mathrm{GPa}$ and $650^{\circ} \mathrm{C}[$ Putiš et al., 1997a]. The Variscan schists of the Gemer-Vepor Contact Domain are characterized by a local occurrence of Fe-Mg-Mn garnet with estimated P-T conditions of $0.6 \mathrm{GPa}$ at $570^{\circ} \mathrm{C}$ [Jeŕábek et al., 2008a]. The schists are intruded by a leucogranite responsible for development of a contact aureole manifested by transversal growth of biotite, chlorite 

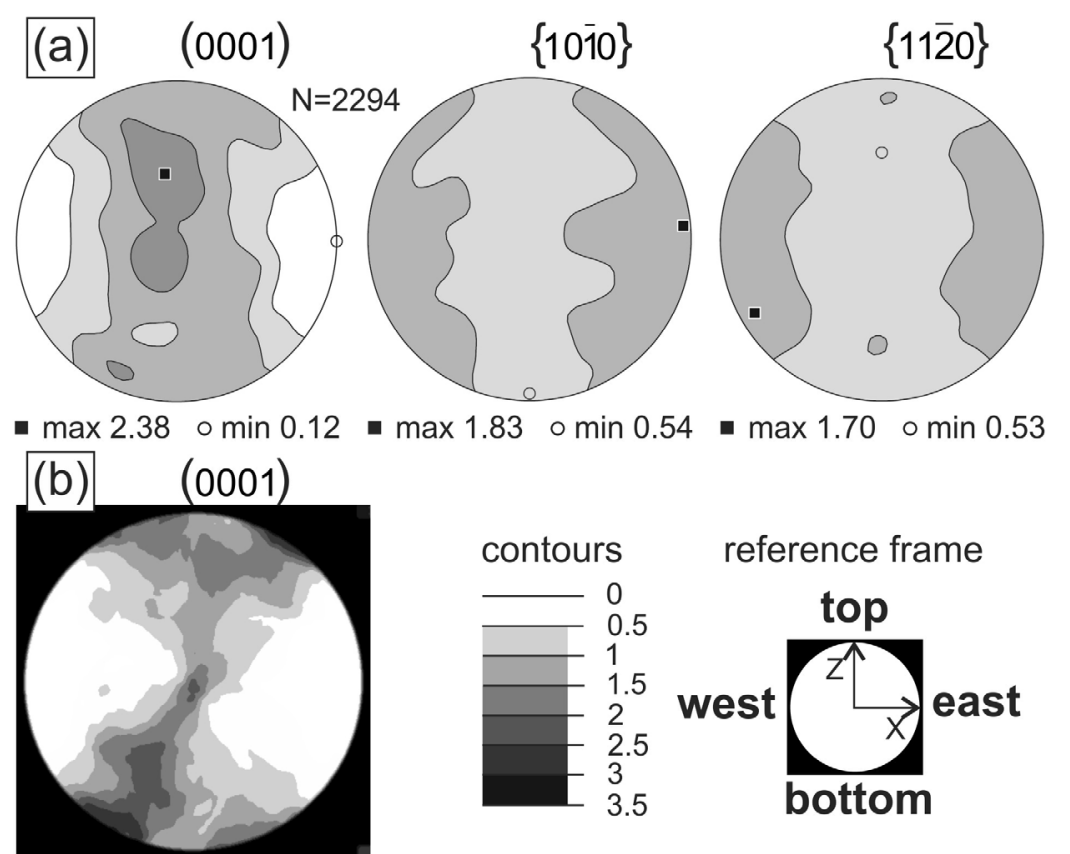

Figure 8. Synoptic diagrams of crystallographic preferred orientation of recrystallized quartz from the Vepor orthogneiss obtained by (a) electron backscattered diffraction and (b) computer-integrated polarization microscopy (for complete data set, see Jeřábek et al. [2007]).

and cordierite [Kamenický, 1977]. Rare quantitative P-T data from garnet bearing migmatites yield metamorphic conditions of $0.5 \mathrm{GPa}$ at $700^{\circ} \mathrm{C}$ [Siman et al., 1996].

\section{2. $\mathrm{Sh}_{\mathrm{am}-\mathrm{gr}}^{1 \mathrm{~A}}$ Fabric}

[30] The $\mathrm{Sh}^{1 \mathrm{~A}}$ fabric is associated with the highest Alpine metamorphic conditions showing a general increase in metamorphic grade toward the south. In the north, the heterogeneous Alpine retrogression of Variscan basement resulted in the formation of chlorite-sericite bearing phyllonites. The imbricated parautochthonous northern Vepor cover shows very low grade Alpine metamorphism proved by an illite crystallinity study [Plašienka et al., 1989]. Toward the south and in the central domain, the Variscan higher temperature metamorphic assemblage is overprinted by the Alpine higher pressure assemblage [Jeřábek et al., 2008a]. This reequilibration is manifested by an overgrowth of Variscan and magmatic garnets by Ca-rich garnet rims with typical prograde compositional zoning (Figures 9a and $9 \mathrm{~b}$ ), growth of epidote and white mica at the expense of feldspars, and growth of biotite and chlorite at the expense of early titanium-rich biotite [e.g., Vrána, 1966; Jeřábek et al., 2008a]. In metapelites, the newly formed garnets are sometimes associated with chloritoid, staurolite, and kyanite that is locally transformed into sillimanite [Méres and Hovorka, 1991; Janák et al., 2001]. In the southern and GemerVepor Contact domains, the Variscan schist together with the leucogranite and its contact aureole are overprinted by the Alpine assemblage characterized by prograde $\mathrm{Ca}$-rich garnet, biotite, chlorite, plagioclase and clinozoisite [Vrána, 1966; Jeř́abek et al., 2008a]. The basement-cover contact along the whole Gemer-Vepor Contact Domain is marked by a horizon of chlorite-chloritoid-kyanite-muscovite-quartz schists [Vrána, 1964; Lupták et al., 2000]. These schists probably represent an Al-rich horizon within the Permian arkose. The Ochtiná nappe phyllite in the hanging wall of the southern Vepor cover is indicative of low-grade metamorphic conditions [Vozárová, 1990], however, the chloritoid bearing schists were also documented in this nappe [Vrána, 1964].

[31] The relationship between deformation and metamorphism is essential for understanding the tectonometamorphic evolution of the Vepor basement. In the deep metapelites, the Variscan garnets fracture and locally get dispersed within the Alpine $\mathrm{Sh}_{\mathrm{am}}^{1 \mathrm{~A}}$ fabric where they are overgrown by the $\mathrm{Ca}$ rich Alpine garnet (Figure 10a). These garnets are typically free of inclusion trails precluding the distinction of its synkinematic or postkinematic origin. On the other hand in the granitoids, small Alpine garnets [Vrána, 1980] with prograde compositional zoning equilibrate within the $\mathrm{Sh}_{\mathrm{am}}^{1 \mathrm{~A}}$ fabric (Figure 10b). A contrasting microstructural observation comes from the Gemer-Vepor Contact Domain where the growth of kyanite and chloritoid, and occasionally also Ca-rich garnet, clearly postdates the $\mathrm{Sh}_{\mathrm{am}}^{1 \mathrm{~A}}$ fabric (Figure 10d). This allows us to distinguish an intertectonic mineral growth stage $\Delta_{\mathrm{kc}}(\mathrm{k}-$ kyanite; c-chloritoid) [Passchier and Trouw, 2005; Beltrando et al., 2008]. Similar microstructural observation has been made in the chloritoid schist of the overlying Ochtiná nappe.

[32] The grade of Alpine metamorphism associated with the $\mathrm{Sh}^{1 \mathrm{~A}}$ fabric in the northern domain increases southward reaching P-T conditions of 0.6 to $0.9 \mathrm{GPa}$ at $540-550^{\circ} \mathrm{C}$ in the metapelites coring the northern domain antiform (Figure 1d) [Putiš et al., 1997a; Jeřábek et al., 2008a]. The $\mathrm{P}-\mathrm{T}$ conditions of $\mathrm{Ca}$-rich garnet bearing assemblages further increase and reach $0.8-1.1 \mathrm{GPa}$ at $550-620^{\circ} \mathrm{C}$ in the metapelites coring the central domain antiform [Janák et al., 2001; Jeřábek et al., 2008a]. An example of P-T estimate associated with the $\mathrm{Sh}_{\mathrm{am}}^{1 \mathrm{~A}}$ fabric in the central domain 

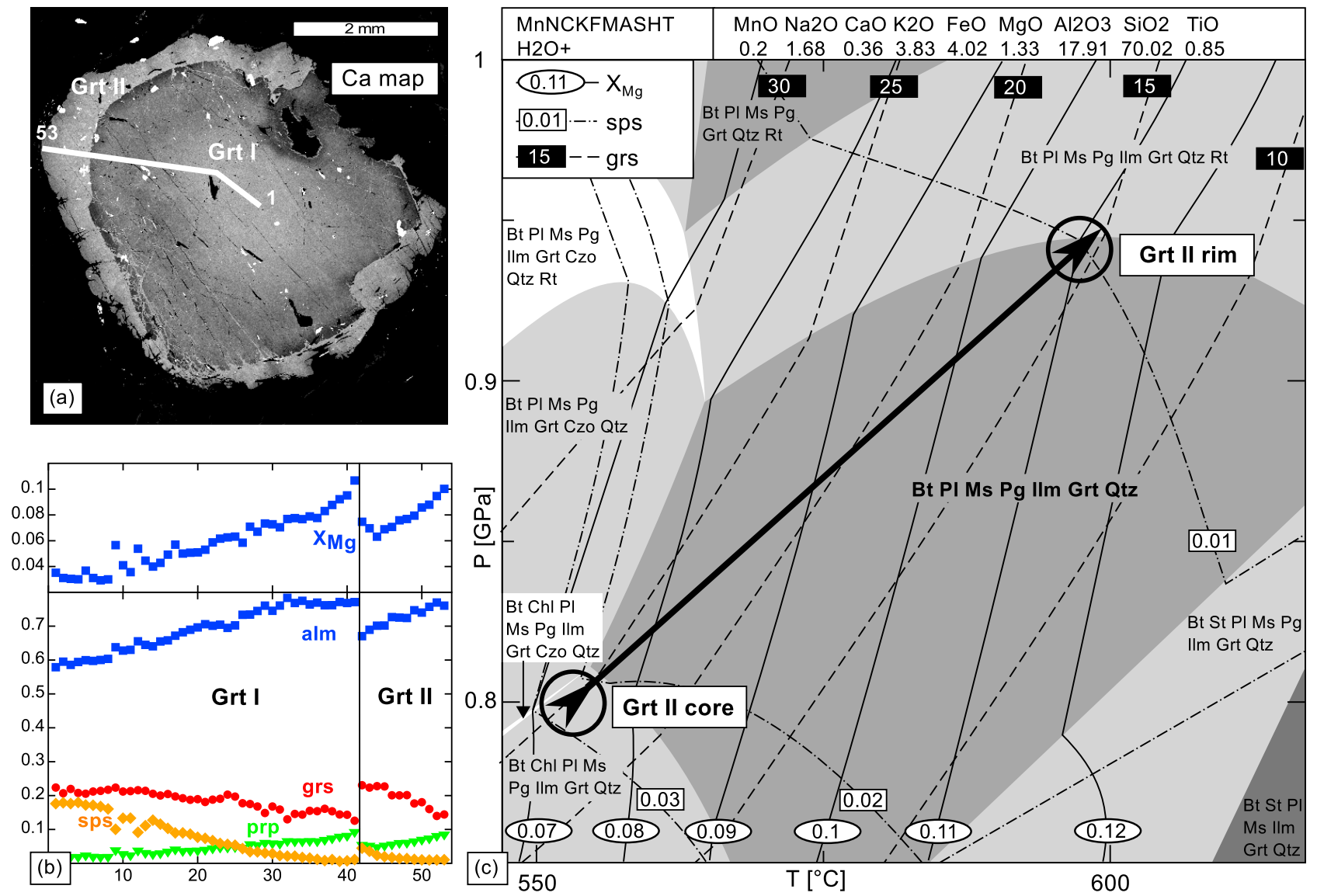

Figure 9. An example of Alpine metamorphic record associated with $\mathrm{Sh}_{\mathrm{am}}^{1 \mathrm{~A}}$ fabric in metapelite sample PP255 (see Figure 12 for location) typical for the central domain antiform: (a) element distribution map of calcium in garnet revealing two generations, the Variscan Grt I and Alpine Grt II, (b) compositional profile across the two garnets, (c) example of a P-T section (P. Jeřábek et al., manuscript in preparation, 2012) calculated in Perple_X in the MnNCKFMASHT system with water in excess using the mineral solution models for chlorite [Holland et al., 1998], white mica [Coggon and Holland, 2002], biotite [White et al., 2007], garnet [White et al., 2000], staurolite [White et al., 2001] and plagioclase [Newton et al., 1980]. P-T section shows prograde P-T path segment based on the core to rim compositional change within Alpine garnet (II). Mineral abbreviations used are after Kretz [1983].

antiform is shown in the P-T section (Figure 9c) calculated by means of thermodynamic modeling in Perple $\mathrm{X}$ (version 6.6.5 [Connolly, 2005]). The calculated P-T conditions correspond to a typical equilibrium mineral assemblage of garnet-biotite-muscovite-paragonite-plagioclase-ilmenitequartz \pm chlorite and clinozoisite (see Figures 9a and 11a). The P-T evolution is based on the core to rim compositional change within the Ca-rich garnet (II) (Figures 9a and 9b) and follows a prograde trend with up to $0.15 \mathrm{GPa}$ and $50^{\circ} \mathrm{C} \mathrm{P}-\mathrm{T}$ increase (Figure 9c). Toward the structural hanging wall, the metamorphic conditions of Alpine metamorphism decrease to $0.55-0.85 \mathrm{GPa}$ at $430-490^{\circ} \mathrm{C}$ in the granitoid and migmatite complex [Vrána, 1980; Jeřábek et al., 2008a], and to $0.45 \mathrm{GPa}$ at $380^{\circ} \mathrm{C}$ and anchimetamorphic conditions in the overlying southern Vepor cover [Lupták et al., 2003]. In the southern and Gemer-Vepor Contact domains, the Variscan schist experienced Alpine reequilibration at $0.8-0.9 \mathrm{GPa}$ and 520-540 C [Janák et al., 2001; Jeřábek et al., 2008a]. The

Figure 10. Micrographs and backscattered electron images showing relationships between metamorphic minerals and deformation structures: (a) $\mathrm{Sh}_{\mathrm{am}}^{1 \mathrm{~A}}$ fabric in metapelite of the Central Vepor Domain with fractured and disintegrated Variscan garnet I overgrown by Alpine garnet II. The trace of $\mathrm{Sh}_{\mathrm{am}}^{1 \mathrm{~A}}$ manifested by shape preferred orientation of micas is folded by upright folds $\mathrm{Fu}^{1 \mathrm{~A}}$. (b) $\mathrm{Sh}_{\mathrm{am}}^{1 \mathrm{~A}}$ in orthogneiss of the Central Vepor Domain with small Alpine garnet II. (c) $\mathrm{Sh}_{\mathrm{am}}^{1 \mathrm{~A}}$ with muscovite and paragonite in metapelite of the Central Vepor Domain crosscut by cleavage $\mathrm{Sv}_{\mathrm{am}}^{1 \mathrm{~A}}$ with secondary chlorite, muscovite and paragonite. (d) $\mathrm{Sh}_{\mathrm{am}}^{1 \mathrm{~A}}$ fabric in chloritoid-kyanite schist of the Southern Vepor Domain overgrown by chloritoid during $\Delta_{\mathrm{kc}}$ and folded by upright crenulations $\mathrm{Fu}^{2 \mathrm{~A}}$ (e) $\mathrm{Sh}_{\mathrm{am}}^{1 \mathrm{~A}}$ in schist of the Gemer-Vepor Contact Domain with chlorite, muscovite and chloritoid crosscut by cleavage $\mathrm{Sh}_{\mathrm{gr}}^{2 \mathrm{~A}}$ with muscovite and chlorite. (f) $\mathrm{Sh}_{\mathrm{am}}^{1 \mathrm{~A}}$ in basement schist of the Gemer-Vepor Contact Domain with Alpine garnet II folded by $\mathrm{Fr}_{\mathrm{gr}}^{2 \mathrm{~A}}$ and crosscut by $\mathrm{Sh}_{\mathrm{gr}}^{2 \mathrm{~A}}$ with muscovite and chlorite. (g) $\mathrm{Sh}_{\mathrm{gr}}^{1 \mathrm{~A}}$ in quartzite of the Gemer-Vepor Contact Domain folded by $\mathrm{Fr}_{\mathrm{gr}}^{2 \mathrm{~A}}$ and crosscut by $\mathrm{Sh}_{\mathrm{gr}}^{2 \mathrm{~A}}$ which is folded by upright crenulations $\mathrm{Fu}_{\mathrm{gr}}^{2 \mathrm{~A}}$. 
thermobarometric estimates for the chloritoid-kyanite schists indicate $0.45 \mathrm{GPa}$ at $530^{\circ} \mathrm{C}$ in the southern Vepor and $0.6-$ $0.8 \mathrm{GPa}$ at $530-560^{\circ} \mathrm{C}$ in the eastern part of the GemerVepor Contact Domain [Lupták et al., 2000]. These estimates contrast with the anchimetamorphic conditions of the overlying southern Vepor cover [Lupták et al., 2003]. The P$\mathrm{T}$ conditions associated with formation of the $\mathrm{Sh}^{1 \mathrm{~A}}$ fabric throughout the Vepor Unit together with the P-T path vectors obtained from core to rim compositional changes in Ca-rich Alpine garnets are summarized in Figure 12.

\section{3. $\mathrm{Sv}_{\mathrm{am}}^{1 \mathrm{~A}}$ Fabric}

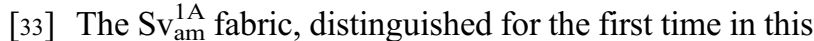
study, has been identified in metapelites of the central domain antiform. This cleavage overprints the garnet bearing $\mathrm{Sh}_{\mathrm{am}}^{1 \mathrm{~A}}$ fabric (Figure 10c) and it is defined by the muscovite-
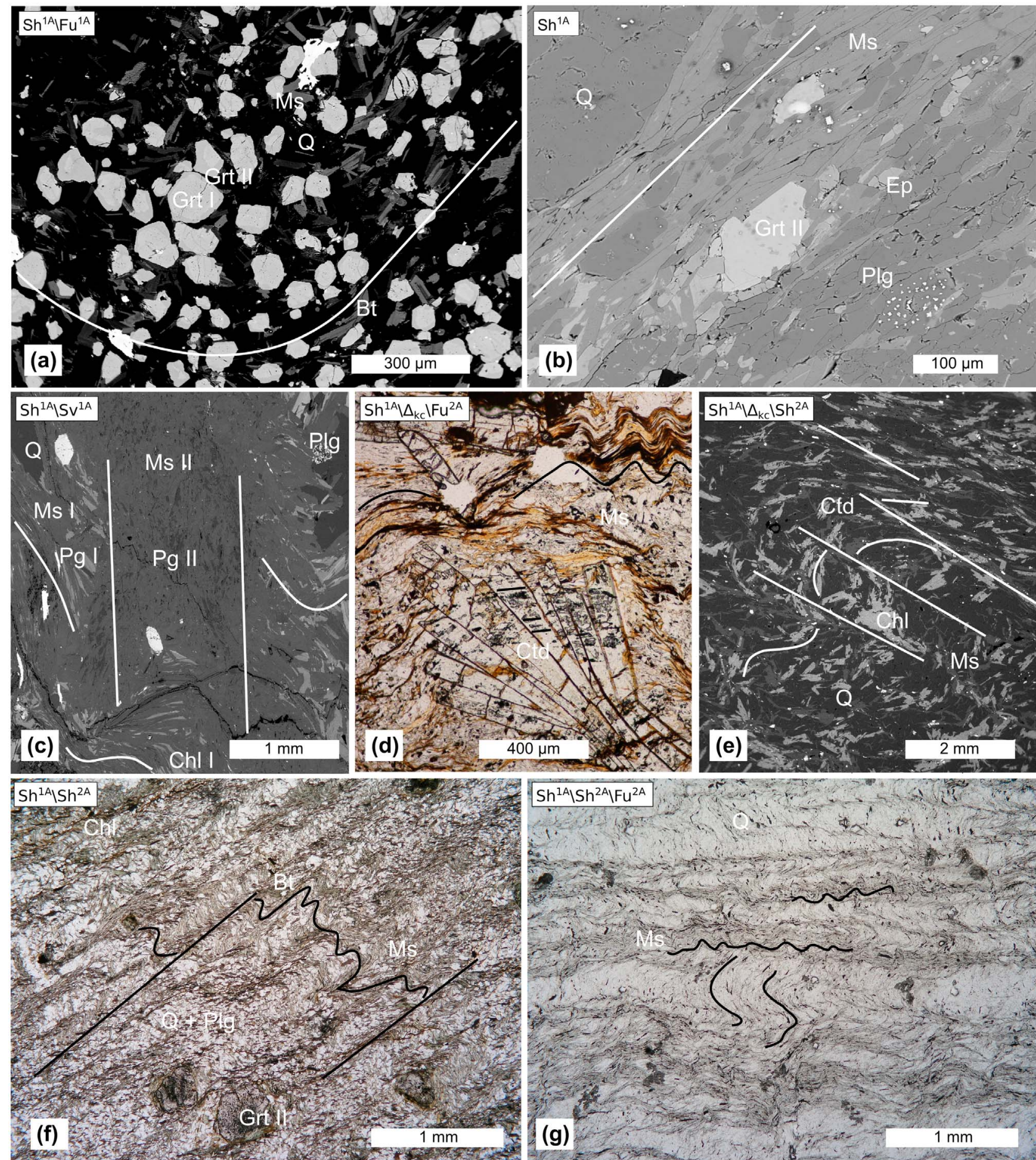

Figure 10 

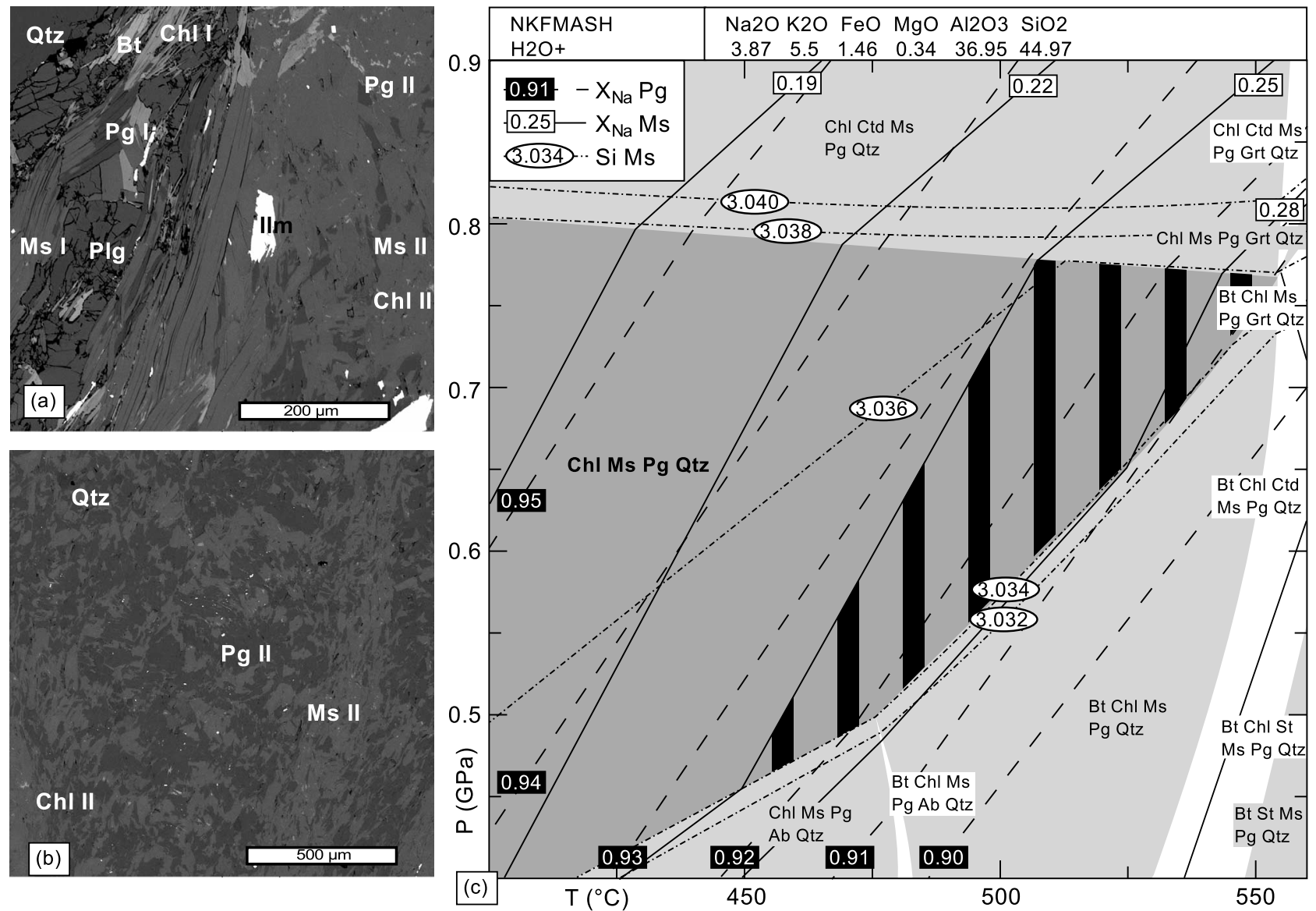

Figure 11. Characterization of P-T conditions of $\mathrm{Sv}_{\mathrm{am}}^{1 \mathrm{~A}}$ fabric in sample PP255 from the central domain antiform (see Figure 12 for location). Microstructural relationship between metamorphic mineral assemblages related to (a) primary $\mathrm{Sh}_{\mathrm{am}}^{1 \mathrm{~A}}$ and (b) secondary $\mathrm{Sv}_{\mathrm{am}}^{1 \mathrm{~A}}$ fabrics backscattered electron image from $\mathrm{Sv}_{\mathrm{am}}^{1 \mathrm{~A}}$ cleavage used to obtain the equilibration volume bulk rock composition for the thermodynamic modeling (c) P-T section calculated in Perple_X in the NKFMASH system with water in excess using the mineral solution models for chlorite [Holland et al., 1998], white mica [Coggon and Holland, 2002], biotite [White et al., 2007], garnet [White et al., 2000], staurolite and chloritoid [White et al., 2001]. Mineral abbreviations used are after Kretz [1983].

paragonite-chlorite-quartz assemblage (Figures 11a and 11b). The P-T conditions of this assemblage were estimated by means of thermodynamic modeling in Perple_X (version 6.6.5 [Connolly, 2005]) using the equilibration volume bulk rock composition (see Figure 11c) obtained from the backscattered electron image in Figure $11 \mathrm{~b}$. In the resulting P-T section, the metamorphic P-T conditions of a relatively large stability field of muscovite-paragonite-chlorite-quartz assemblage are further restricted by the composition of muscovite and paragonite. The $X_{\mathrm{Na}}\left(X_{\mathrm{Na}}=\mathrm{Na} /(\mathrm{K}+\mathrm{Na})\right)$ in paragonite (II) and muscovite (II) reaches maximum values of 0.9 and 0.25 , respectively, restricting our P-T estimate to $0.5-0.8 \mathrm{GPa}$ at $450-550^{\circ} \mathrm{C}$ (Figure $11 \mathrm{c}$ ).

\section{4. $\mathrm{Sh}_{\mathrm{gr}}^{2 \mathrm{~A}}$ Fabric}

[34] Several important metamorphic gaps have been identified throughout the Vepor Unit [Janák et al., 2001; Lupták et al., 2003]. These E-W, mostly pressure gaps and/ or condensed $\mathrm{Sh}_{\mathrm{am}}^{1 \mathrm{~A}}$ isograds occur in the vicinity of the $\mathrm{N}-\mathrm{S}$ trending basement-cover contacts marked by development of the detachment fabric $\mathrm{Sh}_{\mathrm{gr}}^{2 \mathrm{~A}}$ (Figure 3). The $\mathrm{Sh}_{\mathrm{gr}}^{2 \mathrm{~A}}$ shear zones are characterized by growth of a fine-grained muscovite and chlorite and are associated with formation of syndeformational quartz veins and exudations. In the GemerVepor Contact Domain, the degree of retrogression of the $\mathrm{Sh}_{\mathrm{am}}^{\mathrm{AA}}$ by the subparallel $\mathrm{Sh}_{\mathrm{gr}}^{2 \mathrm{~A}}$ fabric (Figures 10e, 10f, and $10 \mathrm{~g}$ ) increases toward the basement-cover contact. In granitoids and migmatites of the central domain, these shear zones reveal extreme modification of a bulk rock composition resulting in the loss of $\mathrm{Ca}$ and $\mathrm{Na}$ and gain of $\mathrm{K}, \mathrm{Mg}$ and $\mathrm{Fe}$ [Putiš et al., 1997b]. The metamorphic temperatures associated with the $\mathrm{Sh}_{\mathrm{gr}}^{2 \mathrm{~A}}$ fabric were estimated to $300^{\circ} \mathrm{C}$ using the fluid inclusion chemistry [Hurai, 1983].

\section{5. $\mathrm{Sv}_{\mathrm{gr}}^{2 \mathrm{~A}}$ Fabric}

[35] $\mathrm{The}_{\mathrm{Sv}}^{2 \mathrm{~A}}$ fabric sporadically developed in the Vepor basement shows low-grade metamorphic conditions characterized by muscovite and chlorite. The associated transpressive shear zone delineating the southeastern Gemer-Vepor contact (Figure 1c) is characterized by near-surface metamorphic conditions [Plašienka et al., 2007]. This shear zone is probably coeval or postdated by an intrusion of the Late 


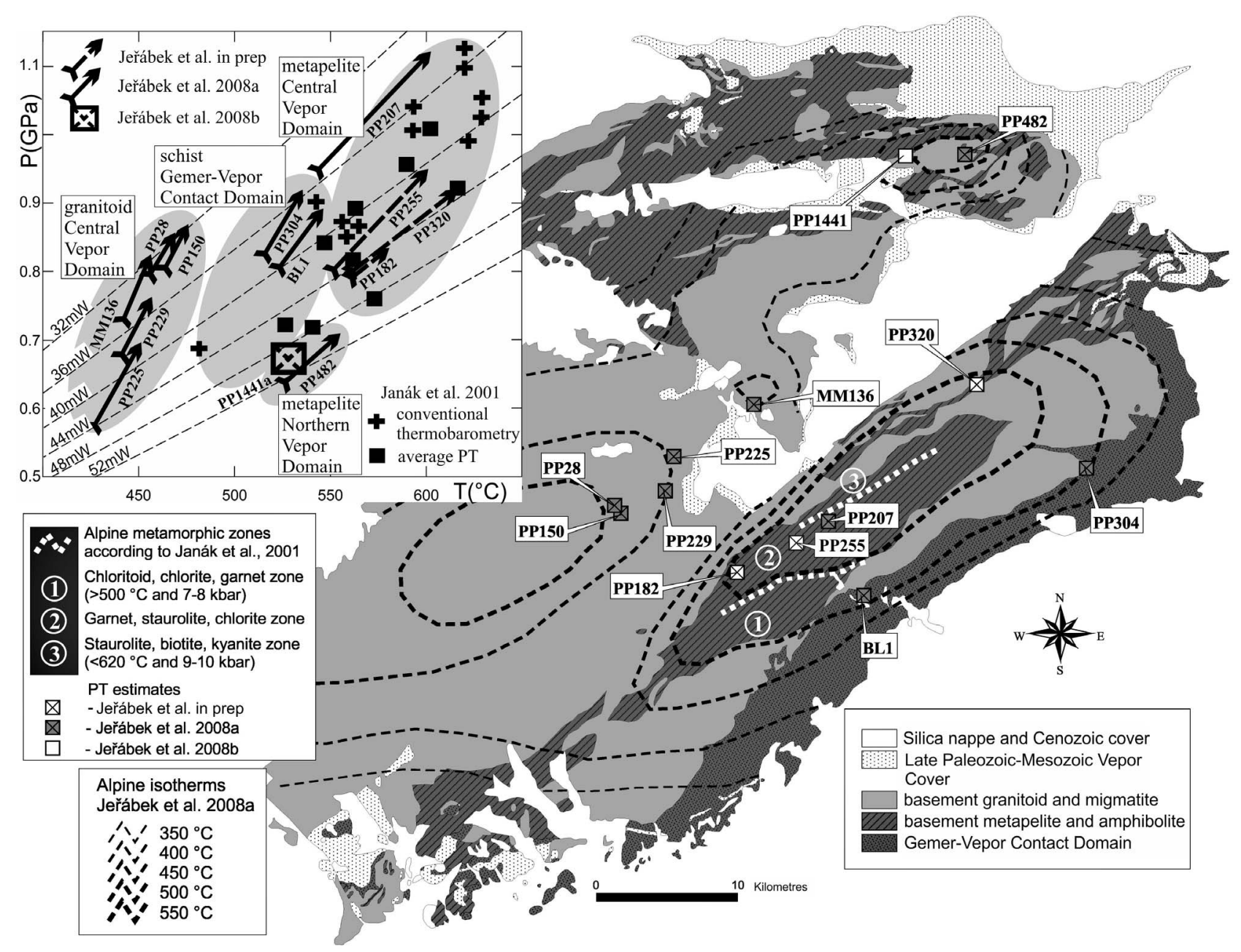

Figure 12. Summary of Alpine P-T conditions and P-T evolution associated with $\mathrm{Sh}_{\mathrm{am}}^{1 \mathrm{~A}}$ fabric based on previous work of Janák et al. [2001] and Jeřábek et al. [2008a, 2008b, manuscript in preparation, 2012]. The arrows in the P-T diagram represent P-T path segments obtained by modeling the core to rim compositional changes in Alpine garnet (II) from individual samples (for example, see Figure 9) located in the lower metapelite and amphibolite complex and upper granitoid and migmatite complex of the Central and Northern Vepor Domain and the Gemer-Vepor Contact Domain (see map). The metamorphic zones and isotherms in the map are after Janák et al. [2001] and Jeŕábek et al. [2008a], respectively. The P-T diagram shows steady state geotherms for standard continental crust characterized by exponentially decreasing radioactive heat production $\left(9.6 \times 10^{-10} \mathrm{~W} / \mathrm{kg}\right.$ with characteristic depth of $\left.15 \mathrm{~km}\right)$ calculated for various mantle heat flows [Turcotte and Schubert, 2002].

Cretaceous Rochovce granite [Hraško et al., 1999; Poller et al., 2001]. Although this granite was only detected in boreholes, it is associated with numerous surface occurrences of pegmatite dikes and a contact aureole with andalusite and cordierite [Vozárová, 1990].

\section{Chronological Constraints on the Tectonometamorphic Evolution of the Vepor Dome}

[36] Critical constraints for the conceptual model of formation of the Vepor Dome are the ages of individual deformation phases. As direct dating of deformation fabrics is rather limited due to available geochronological techniques, the ages of individual fabrics have been inferred by linking the metamorphic grade with closing temperatures of available ${ }^{40} \mathrm{Ar} /{ }^{39} \mathrm{Ar}$ ages from the Vepor and Gemer units, and by considering the stratigraphic record of the northerly Fatric basin (Figure 13).

[37] The earliest ages related to the Cretaceous convergence in the Central West Carpathians are represented by ${ }^{40} \mathrm{Ar} /{ }^{39} \mathrm{Ar}$ and $\mathrm{K} / \mathrm{Ar}$ data which are associated with the development of low-grade Gemer Cleavage Fan between 125 and $105 \mathrm{Ma}$ [Dallmeyer et al., 2008; Hurai et al., 2008]. Northward progression of the convergence is indicated by an inversion of the northerly Fatric basin at Aptian-Albian boundary ( $112 \mathrm{Ma})$ [Plašienka, 1995b] followed by an extensive Albian-Cenomanian ( $\sim 105-95 \mathrm{Ma})$ flysch sedimentation in the Fatric domain [Kissová et al., 2005]. This flysch complex documents a period of main orogenic thickening of the southerly Gemer-Vepor wedge system. The thickening is in part coeval with the development of the 


\section{Cumulative Distribution Function ${ }^{40} \mathrm{Ar} /{ }^{39} \mathrm{Ar}$ and $\mathrm{K} / \mathrm{Ar}$ ages}

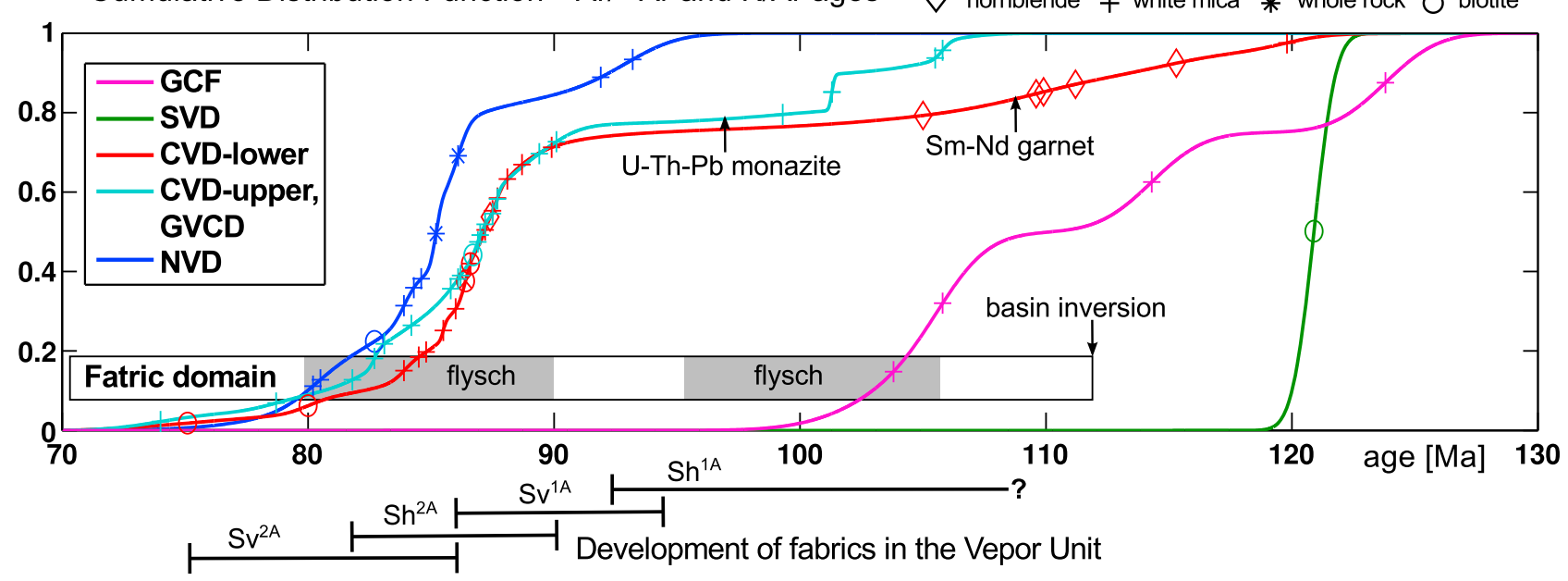

Figure 13. Cumulative Distribution Function diagram for ${ }^{40} \mathrm{Ar} /{ }^{39} \mathrm{Ar}$ and $\mathrm{K} / \mathrm{Ar}$ ages from the Gemer and Vepor Units plotted separately for individual domains: GCF, Gemer Cleavage Fan (sources 1 and 2), SVD, southern Vepor Domain (source 3); CVD-lower, lower metapelite and amphibolite complex of the Central Vepor Domain (sources 2-9); CVD-upper, upper granitoid and migmatite complex and southern Vepor cover, and GVCD, Gemer-Vepor Contact Domain (sources 2, 3, 4, 6, 7, 9): NVD, Northern Vepor Domain (sources 5,8,9). The ages used to plot individual cumulative curves were taken from the following sources: (1) Dallmeyer et al. [2008], (2) Hurai et al. [2008], (3) Král' et al. [1995], (4) Kováčik et al. [1996], (5) Maluski et al. [1993], (6) Dallmeyer et al. [1993], (7) Dallmeyer et al. [1996], (8) Dallmeyer et al. [2005], and (9) Putiš et al. [2009]. Garnet Sm-Nd age for the lower metapelite and amphibolite complex [Lupták et al., 2004] and U-Th-Pb monazite age for the Gemer-Vepor Contact Domain [Bukovská et al., 2012] are also indicated. For timing of sedimentary record in the Fatric domain, see Plašienka [1995a, 2003] and Kissová et al. [2005]. Presumed timing of individual deformation fabrics in the Vepor Unit is also shown in the figure (see text for explanation).

$\mathrm{Sh}^{1 \mathrm{~A}}$ fabric and peak Alpine metamorphism in the Vepor Unit. Indeed, an older population of ${ }^{40} \mathrm{Ar} /{ }^{39} \mathrm{Ar}$ ages from the Vepor Unit (Figure 13) reveals hornblende ages between 115 and $105 \mathrm{Ma}$ in the deep metapelite and amphibolite complex of the central Vepor [Kovácik et al., 1996] and white mica ages around $105-100 \mathrm{Ma}$ in the weakly metamorphosed southern Vepor cover [Dallmeyer et al., 1996; Putiš et al., 2009]. These ages are consistent with somehow preliminary $\mathrm{Sm}-\mathrm{Nd}$ whole rock-garnet isochron indicating $108.8 \pm 5.6 \mathrm{Ma}$ in the deep metapelites [Lupták et al., 2004] and by the U-Th-Pb ICP-MS dating of monazite indicating $97 \pm 4 \mathrm{Ma}$ in the chloritoid-kyanite schists near the basement-cover contact [Bukovská et al., 2012]. The latter age is associated with a transversal growth of chloritoids related to the intertectonic metamorphic stage $\Delta_{\mathrm{kc}}$, postdating the $\mathrm{Sh}^{1 \mathrm{~A}}$ and predating the $\mathrm{Sh}^{2 \mathrm{~A}}$ fabrics (Figures 10d and 10e). Again, the northward progression of the convergence is reflected by younger ${ }^{40} \mathrm{Ar} /{ }^{39} \mathrm{Ar}$ white mica ages from the low-grade $\mathrm{Sh}^{1 \mathrm{~A}}$ shear zones of the Northern Vepor Domain (Figure 13) indicating 95-90 Ma [Putiš et al., 2009]. These ages are likely to correspond to the southward underthrusting of the Fatric basement which was completed by the Turonian as indicated by the latest movements of the Krížna (Fatric) nappe.

[38] The large quantity of ${ }^{40} \mathrm{Ar} /{ }^{39} \mathrm{Ar}$ white mica cooling ages from the deep metapelite and amphibolite complex shows slightly older ages of 87-85 Ma for the central domain compared to 86-84 Ma for the northern domain (Figure 13). These ages occur within two large-scale antiforms associated with the development of retrograde $\mathrm{Sv}^{1 \mathrm{~A}}$ and $\mathrm{Sv}^{2 \mathrm{~A}}$ fabrics. Similar ${ }^{40} \mathrm{Ar} /{ }^{39} \mathrm{Ar}$ white mica cooling ages spanning between 88 and 83 Ma have been reported from the upper granitoid and migmatite complex, southern Vepor cover, and Gemer-Vepor Contact Domain [Dallmeyer et al., 2005; Putiš et al., 2009], which are affected by the low-grade $\mathrm{Sh}^{2 \mathrm{~A}}$ detachment fabric (Figure 3). The exhumation of the Vepor basement is accompanied by a ConiacianSantonian ( 90-80 Ma) Gosau-type clastic sedimentation [Plašienka et al., 1997]. The late stages of exhumation are documented by the available zircon and apatite fission track data from the Gemer and Vepor units spanning between $\sim 89$ and 54 Ma [Král', 1977; Plašienka et al., 2007].

\section{Discussion}

\subsection{Kinematic and Temporal Evolution of the Vepor Dome}

[39] To understand the kinematic evolution of the Vepor Dome we need to place its tectonic evolution into the context of the Gemer-Vepor-Fatric convergent system (Figure 1). The earliest stages of the Cretaceous convergence are constrained by development of the large-scale cleavage fan structure in the southerly hanging wall Gemer Unit at $\sim 125 \mathrm{Ma}$ [Hurai et al., 2008]. The nappe stacking of the Gemer Unit over the Vepor Unit [Lexa et al., 2003] is marked by a deposition of Albian-Cenomanian flysch in the northerly Fatric domain. The flysch contains pebbles from the Gemer and overlying Meliata units which show Albian- 
Cenomanian fission track ages [Kissová et al., 2005]. The youngest $\sim 92 \mathrm{Ma}$ thrusting in the northern Vepor, which is likely to be associated with the southward underthrusting of the Fatric lithosphere [Tomek, 1993; Putiš et al., 2009], is rapidly followed by an exhumation of the whole Vepor basement accompanied with deposition of the second flysch sequence of Coniacian-Santonian age (Figure 13).

\subsubsection{Early Cretaceous Thickening}

[40] In the Vepor Unit, the early Alpine stages $(\sim 125-$ $100 \mathrm{Ma}$ ) of $\mathrm{N}-\mathrm{S}$ convergence (Figure 13) are associated with steepening (Figure 14) of the originally subhorizontal to gently northward dipping Variscan fabrics $\mathrm{S}^{\mathrm{V}}$ [Bezák et al., 1997]. The steepening occurred prior to the development of subhorizontal $\mathrm{Sh}^{1 \mathrm{~A}}$ fabric which is indicated by highangle relationships between the two fabrics (Figure 5c) as well as by the results of our combined finite strain and texture analyses. Jeŕábek et al. [2007] showed that the dynamic recrystallization of quartz aggregates occurred during an E-W orogen parallel stretching associated with the development of subhorizontal $\mathrm{Sh}^{1 \mathrm{~A}}$ fabric. The crystal preferred orientation of recrystallized quartz is characterized by single or crossed girdle type I c axis patterns (Figure 8) that are typical for a plane strain deformation [Lister and Hobbs, 1980; Schmid and Casey, 1986]. The plane strain deformation, however, contrasts with prolate and oblate shapes of the studied aggregates (Figure 6). The aggregate shapes should therefore reflect a fabric superposition rather than variations in flow symmetry. With this respect, the origin of the constrictional strain reported in this work contrasts with a model of instantaneous orogen parallel constriction due to unloading of tectonic forces proposed by Duclaux et al. [2007]. The question arises whether the constrictional strains in the Vepor Unit resulted from superposition of the $\mathrm{Sh}^{1 \mathrm{~A}}$ over $\mathrm{S}^{\mathrm{V}}$ or the $\mathrm{Sv}^{1,2 \mathrm{~A}}$ over $\mathrm{Sh}^{1 \mathrm{~A}}$. Our complementary analysis of the aggregate internal fabrics has revealed an apparent conflict between aggregate shapes and their internal grain SPO (Figure 7), which most likely stems from their different capacity to record incremental and finite strains. Thus while the aggregate shape is a finite strain marker, the grain SPO is mostly controlled by an instantaneous strain [Ree, 1991; Passchier and Trouw, 2005]. Accordingly, the grain SPOs record subvertical shortening within the prolate aggregates (Figure 7a) and subhorizontal shortening within the oblate aggregates (Figure 7b). Consequently, the constrictional strains are interpreted as the superposition of the previously steepened Variscan fabrics $\mathrm{S}^{\mathrm{V}}$ by subhorizontal Alpine $\mathrm{Sh}^{1 \mathrm{~A}}$ fabric. Furthermore, the domain distribution of prolate and oblate fabrics throughout the Vepor orthogneiss (Figure 6) may indicate an overprint of folded $\mathrm{S}^{\mathrm{V}}$ fabric within vertical limbs and horizontal hinge zones of large-scale early Alpine folds.

[41] Similarly to the basement gneiss, the bedding in the Late Paleozoic-Mesozoic cover was also steepened prior to the development of $\mathrm{Sh}^{1 \mathrm{~A}}$ fabric as documented by the highangle relationships of $\mathrm{S}^{0}$ and $\mathrm{Sh}^{1 \mathrm{~A}}$ at the periphery of the Vepor Dome (Figures 4a, 4b, and 4c). The associated local steepening of the basement-cover contacts is documented by the development of large-scale recumbent folds $\mathrm{Fr}^{1 \mathrm{~A}}$ with the cover-basement-cover sequence in the Gemer-Vepor Contact Domain (Figure 2e). Based on these evidences, we assume that not only the hanging wall Gemer Unit [Lexa et al., 2003] but also the Vepor basement and cover experienced considerable shortening during the initial Early Cretaceous convergent stages (Figure 14).

[42] Geochronological data indicate that the development of subhorizontal metamorphic fabric $\mathrm{Sh}^{1 \mathrm{~A}}$ in the lower and middle Veporic crust $(\sim 108-95 \mathrm{Ma})$ is coeval with the above described mostly upper crustal thickening of the Gemer-Vepor system (Figure 14). This observation is further supported by the prograde metamorphic character of mineral assemblages defining the $\mathrm{Sh}^{1 \mathrm{~A}}$ fabric (Figure 9). The prograde metamorphic character of the $\mathrm{Sh}^{1 \mathrm{~A}}$ has been demonstrated in all crustal levels of the Vepor Unit (Figure 12). Thus the peak metamorphism is attained with a normal metamorphic field gradient recording: (1) syntectonic growth of kyanite, staurolite and garnet at $1.1 \mathrm{GPa}$ and $600^{\circ} \mathrm{C}$ in the deepest metapelites, (2) growth of garnet and dynamic recrystallization of quartz at $0.85 \mathrm{GPa}$ and $480^{\circ} \mathrm{C}$ in the structurally higher orthogneiss, and (3) growth of chlorite and phengite at $0.45 \mathrm{GPa}$ and $380^{\circ} \mathrm{C}$ in the structurally highest southern Vepor cover [Janák et al., 2001; Lupták et al., 2003; Jeřábek et al., 2008a]. The increase in pressure and temperature of up to $0.15 \mathrm{GPa}$ and $50^{\circ} \mathrm{C}$ recorded by individual samples (Figure 12) collected from the $\mathrm{Sh}^{1 \mathrm{~A}}$ fabric suggests a process of lateral $\mathrm{E}-\mathrm{W}$ spreading of the deep Vepor crust during the progressive thickening of the upper crustal levels. This model is consistent with a pure shear dominated orogen-parallel flow revealed by nonsystematic sense of shear (Figure 3) and overall orthorombic symmetry of quartz fabrics (Figure 8) in the Vepor orthogneiss [Jeřábek et al., 2007, 2008a].

\subsubsection{Late Cretaceous Doming}

[43] The exhumation history ( $\sim 90-83 \mathrm{Ma})$ is marked by distinct structural and metamorphic evolutions in different parts of the Vepor Dome. The Alpine metamorphic isotherms presented in the metamorphic map in Figure 12 document an overall increase in metamorphic grade from north to south, which is subsequently modified by heterogeneous exhumation of deep seated rocks within two largescale antiforms [Jerábek et al., 2008a]. In the central domain antiform, the subhorizontal $\mathrm{Sh}^{1 \mathrm{~A}}$ foliation with P-T estimates of $0.8-0.95 \mathrm{GPa}$ and $550-600^{\circ} \mathrm{C}$ (Figure 9) is overprinted by the vertical cleavage $\mathrm{Sv}^{1 \mathrm{~A}}$ with $\mathrm{P}-\mathrm{T}$ estimate of $0.5-0.8 \mathrm{GPa}$ and $450-550^{\circ} \mathrm{C}$ (Figures 11 and 14). The retrograde conditions of the $\mathrm{Sv}^{1 \mathrm{~A}}$ together with a relatively small difference between the peak metamorphic conditions of both fabrics indicate that the exhumation of deep seated rocks in the Vepor Dome coincides with the onset of largescale folding. Moreover, the coincidence of pressure peak and temperature maximum along the P-T path together with locally observed overgrowth of kyanite by sillimanite [Janák et al., 2001] advocates the near-adiabatic type of exhumation within the cores of the large-scale antiforms.

[44] Subsequent progressive growth of the dome induced development of heterogeneous array of greenschist facies shear zones and eastward detachments $\mathrm{Sh}^{2 \AA}$ in the upper part of the dome. At the same time, the progressively steepened dome margins were reworked by recumbent folds $\mathrm{Fr}^{2 \mathrm{~A}}$ and associated cleavage $\mathrm{Sh}^{2 \mathrm{~A}}$ (Figure 14). These folds are characterized by NE-SW trending axes along the southeastern margin of the dome and $\mathrm{N}-\mathrm{S}$ trending axes along its eastern margin. Such a semiconcentric distribution of the "cascade" type $\mathrm{Fr}^{2 \mathrm{~A}}$ folds is a diagnostic feature of vertical growth of a crustal dome that is associated with marginal detachments 


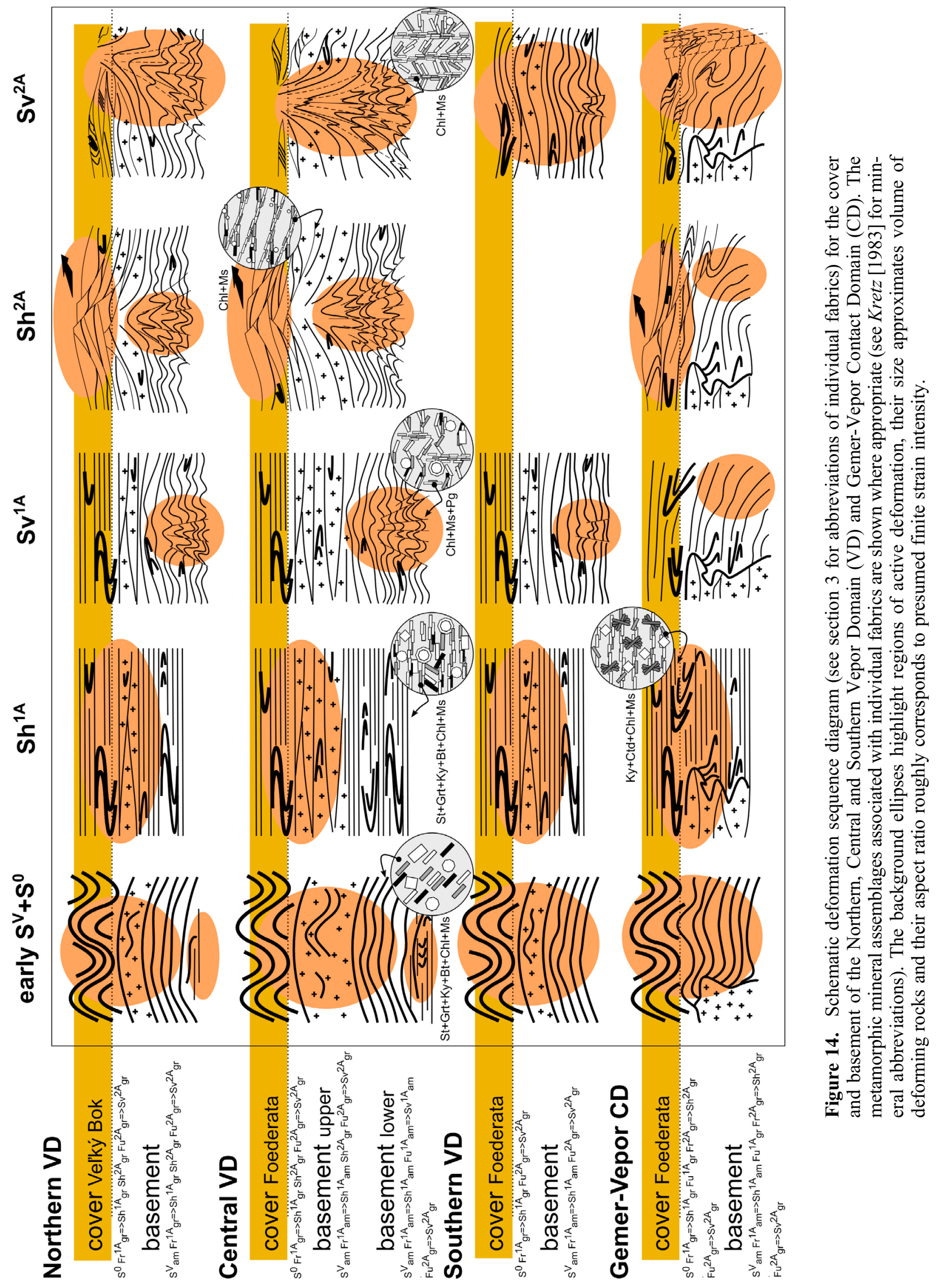


[Burg et al., 2004]. The doming process is most pronounced in the central and eastern parts of the Vepor Unit and vanishes toward the west where also the detachment fabrics are missing (Figures 3 and 14). The spatial variations in successions of deformation fabrics (Figure 14) are indicative of (1) growth of cuspate antiforms in the deepest part of the Vepor basement concomitant with the growth of regionalscale dome, (2) ductile thinning mechanism operating in the upper crustal apical parts of the dome, and (3) formation of marginal detachments affecting the previously steepened eastern and southeastern margins of the asymmetrically growing dome.

[45] The late stages $(\sim 83-75 \mathrm{Ma})$ of growth of the Vepor Dome are characterized by continual $\mathrm{N}-\mathrm{S}$ shortening and upright folding $\mathrm{Fu}^{2 \mathrm{~A}}$ (Figures $4 \mathrm{f}$ and $5 \mathrm{e}-5 \mathrm{~g}$ ) as well as by the formation of steep NE-SW trending sinistral transpressive shear zones. These shear zones developed within the two large-scale cusp-like antiforms in the internal part of the Vepor Dome and along its southeastern edge (Figure 3) [Lexa et al., 2003]. Sinistral transpression within these belts is indicated by (1) tightening of the $\mathrm{Fu}^{1 \mathrm{~A}}$ folds by $\mathrm{Fu}^{2 \mathrm{~A}}$ (Figure 14), (2) development of steep axial planar cleavage $\mathrm{Sv}^{2 \mathrm{~A}}$ with lower greenschist facies conditions, and (3) anticlockwise rotation of the $\mathrm{Fu}^{2 \mathrm{~A}}$ fold hinges toward the NESW direction (Figure 3). Outside these zones, both $\mathrm{Sh}^{2 \mathrm{~A}}$ and $\mathrm{Sh}^{1 \mathrm{~A}}$ are affected by small-scale crenulations with E-W trending axes. This microfolding is also responsible for development of the steep grain SPO within the oblate quartz aggregates in the central domain orthogneiss (Figures $7 \mathrm{~b}$ and $7 \mathrm{c})$. The map view of the $\mathrm{Fu}^{2 \mathrm{~A}}$ folds in Figure 3 reveals an alternation of broader domains characterized by either pure shear dominated folding (E-W $\mathrm{Fu}^{2 \mathrm{~A}}$ axes) or wrench dominated shearing (NE-SW Fu ${ }^{2 \mathrm{~A}}$ axes, see Figures $2 \mathrm{~b}$ and 3 ). This indicates an important role of strain partitioning at the scale of the Vepor Dome. We propose that this late tectonic evolution results from a buttressing effect and does not significantly contribute to the exhumation and vertical growth of the dome.

\subsection{Dynamics of Lower Crustal Flow and the Dome Formation}

\subsubsection{Lower Crustal Flow}

[46] In general, a horizontal flow of ductile lower crust is possible either due to drag of underlying lithosphere [e.g., Beaumont et al., 2006] or thanks to lateral pressure gradients generated either by variations in density distribution above the low-viscosity lower crustal rocks [McKenzie et al., 2000; Beaumont et al., 2006] or by an inverse density gradient [Huet et al., 2011]. In the first case the flow is dominantly noncoaxial and associated with burial while in the latter case the generally coaxial flow occurs along negative pressure gradient implying pressure drop and/or exhumation of deep seated rocks. The Central West Carpathians wedge-type setting together with the southward underthrusting of the Fatric lithosphere might invoke a drag-related burial of the Vepor Unit. In our case, however, the classical model of wedge dynamics [Platt, 1986; Allemand and Lardeaux, 1997] can be excluded due to the prevailing coaxiality of the E-W flow and its orthogonality to the presumed dragrelated structures. Moreover, the relatively short time span between the peak metamorphism in the deep Vepor and the onset of underthrusting of the Fatric domain (Figure 13) together with rather limited total displacement of the underthrusted basement do not favor the wedge-related scenario.

[47] The above described metamorphic, geochronological and kinematic constraints indicate that the dynamics of ductile flow in the deep Vepor crust was controlled from the top and governed by the northward progression of the Gemer crustal nappe. The kinematic response of the Vepor Unit to the progressive increase of vertical load is controlled by two key parameters: (1) extremely low viscosity of the lower crust due to low resistance of mica-rich metapelites at $550-650^{\circ} \mathrm{C}$ (as low as $\sim 10^{13} \mathrm{~Pa}$ s [e.g., Mariani et al., 2006]) and (2) normal density gradient characterized by slightly higher average density of the deep garnet-bearing metapelites $\left(\sim 2.75 \mathrm{~g} / \mathrm{cm}^{3}\right)$ compared to the overlying felsic granitoids and migmatites $\left(\sim 2.65 \mathrm{~g} / \mathrm{cm}^{3}\right)$ [cf. Vigneresse and Bouchez, 1997]. In other words, with the absence of buoyancy forces, the horizontal flow within the mica schist dominated lower crust has been primarily controlled by the horizontal pressure gradients related to lateral variations in density distribution or differential loading. The mean velocity $u$ of flow driven by a pressure gradient could be estimated according to equation:

$$
u=\frac{1}{2 \mu} \frac{d p}{d x}\left(z^{2}-h z\right)
$$

where, $z$ is depth, $d p / d x$ is horizontal pressure gradient and $\mu$ is viscosity [Turcotte and Schubert, 2002]. This type of equation has been applied to estimate timescales of the lower crustal flow resulting from lateral variations in the crustal thickness underneath the Tibetan Plateau [Bird, 1991; Clark and Royden, 2000]. There the viscosity estimates range between $10^{16} \mathrm{~Pa}$ s to $10^{21} \mathrm{~Pa}$ s for channel thickness of $\sim 15 \mathrm{~km}$. For these viscosities and existing topography, the redistribution of the lower crustal material within the channel occurs in the orders of millions to tens of millions years. Our estimates suggest that the viscosity of metapelites during the metamorphic peak was up to 4 orders of magnitude lower compared to the average values for the Tibetan plateau. Taking into account that the possible thickness of the lowviscosity metapelite-rich lower crust in the Vepor Unit could be up to $10 \mathrm{~km}$ (as estimated from the pressure difference between metapelites and overlying orthogneiss), its lateral redistribution could have been 4 orders of magnitudes faster, i.e., nearly instantaneous.

[48] The main difference between the lower crustal flow in the Vepor Unit and typical channel flow is the pressure increase revealed by the studied case. In general, to maintain the prograde character of subhorizontal fabrics the loadbuilding or thickening mechanism operating in the upper crust has to be not only coeval but also more efficient. It is widely accepted that orogenic thickening leads to an excess and disequilibrium in gravitational potential energy [e.g., Platt, 2007]. In large hot orogens, the gravity equilibration via horizontal material transfers [e.g., Henk, 1999; Beaumont et al., 2006] occurs only at late stages of the orogen development due to the time lag of thermal maturation and associated rheological weakening of the orogenic lower crust. However, the low viscosity of the Veporic lower crust is an inherited feature allowing nearly instantaneous kinematic response to the surpluses in gravitational potential energy. Therefore, it is likely that the horizontal flow in the Vepor 


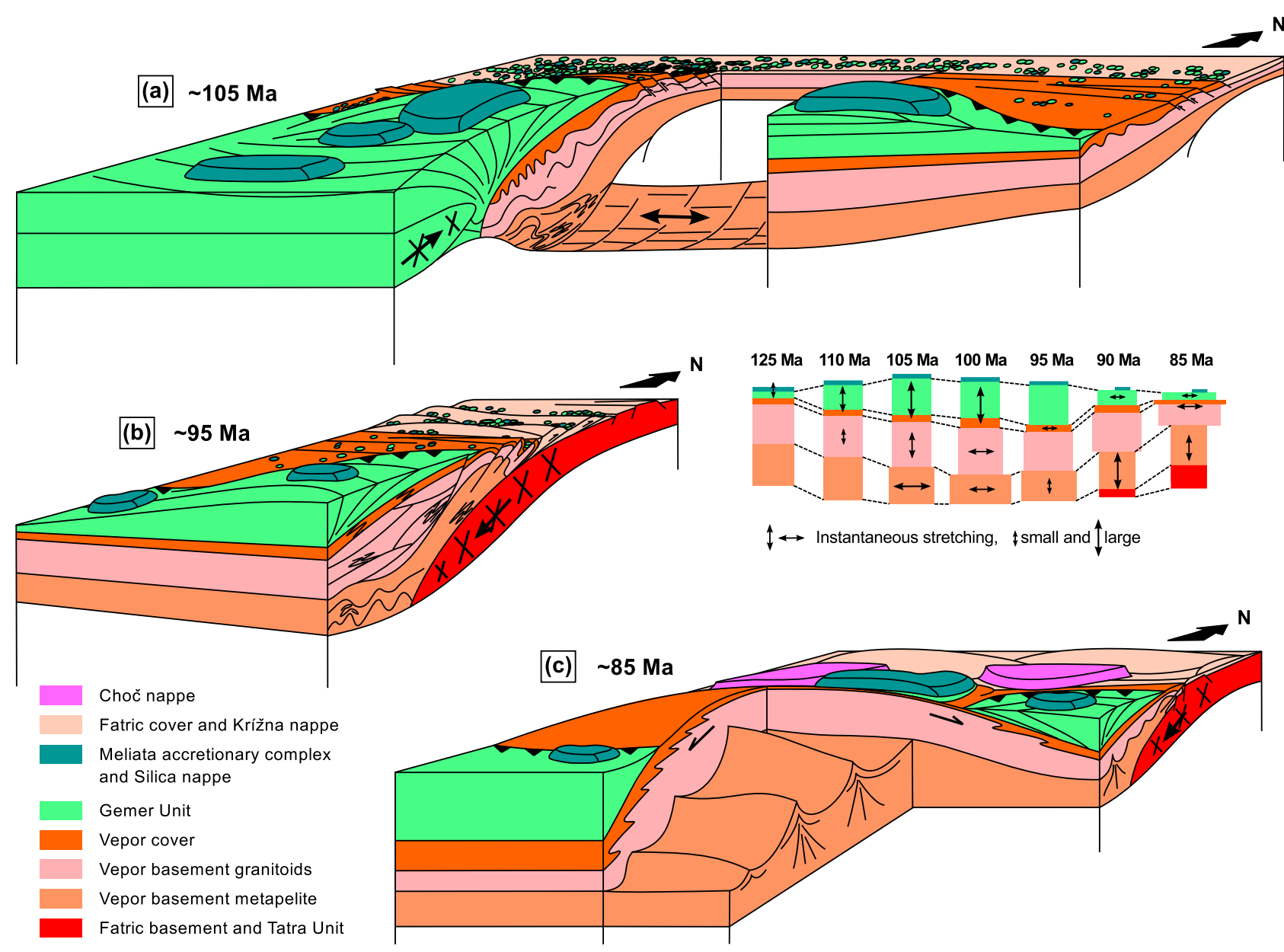

Figure 15. The Cretaceous tectonic evolution of the Central West Carpathians wedge reflecting the main evolutionary stages in the Vepor Unit. The crustal columns to the right indicate periods of thickening and thinning of individual crustal levels.

Unit triggered by the variations in gravity potentials would operate simultaneously with overall thickening and burial (Figure 15a). Indeed, the overlap between ages related to the upper crustal thickening $(\sim 125-100 \mathrm{Ma})$ and lower crustal thinning $(\sim 108-95 \mathrm{Ma})$ strongly supports this interpretation (Figure 13). Moreover, simultaneous operation of the upper crustal thickening and lower crustal thinning has been already predicted by the modeling results of Seyferth and Henk [2004]. We believe that the "unique" record of the lower crustal flow in the small-scale intraorogenic Vepor Dome represents an example of a process designated as "Inverse Ductile Thinning." Further, we expect that similar lower crustal response to the heterogeneous upper crustal thickening occurs elsewhere namely in large hot orogens.

\subsubsection{Dome Formation}

[49] The geochronological data indicate that the onset of exhumation of the whole Vepor basement follows directly the low-grade shearing in the northern Vepor related to the underthrusting of the Fatric lithosphere (Figure 13). The onset of doming in the Vepor Unit is marked by an abrupt change from vertical shortening and E-W horizontal stretching to $\mathrm{N}-\mathrm{S}$ horizontal shortening within the deep Vepor crust. Furthermore, the northward gravitational sliding of the Krížna nappe over the Tatra Unit together with the break in flysch sedimentation in the Fatric Domain between 95 and 90 Ma (Figure 13) [Kissová et al., 2005; Prokešová et al., 2012] implies general relaxation of horizontal stresses in the upper crust of the Gemer-Vepor system. These evidences indicate that the originally top-driven tectonic mechanism switched to bottom-driven [Tikoff et al., 2002]. We suggest that this major change is related to the progression in underthrusting of the rigid Fatric crustal wedge, so that its tip reached greater depths thereby triggering the upright folding $\mathrm{Fu}^{1 \mathrm{~A}}$ in the deep Veporic crust (Figure 15b). Consequently, the lower crustal material started to flow vertically along narrow cuspate structures developed at the metapelite-granitoid interface. This heterogeneous exhumation of the deep metapelites resulted in overall doming of the Vepor Unit and associated ductile thinning in the shallow crustal levels. The existing ${ }^{40} \mathrm{Ar} /{ }^{39} \mathrm{Ar}$ white mica cooling ages as well as structural data point to simultaneous crustalscale folding and detachment-related unroofing of the Vepor basement (Figures 13 and 15c). Such interplay between folding and detachment faulting has been previously described by Mancktelow and Pavlis [1994]. In their model, however, the horizontal shortening postdates an onset of deep detachment system and vertical thinning, and thus the upright folding compensates for reduction in crustal 
thickness. In contrast in our concept, the lower crustal folding induces upper crustal thinning which thus compensates for excess in crustal thickness.

\section{Conclusions and Geodynamic Integration of the Vepor Dome}

[50] The West Carpathians represents a tectonic domain within the ALCAPA continental block, which was extruded from the Alpine region toward northeast during Tertiary [e.g., Ustaszewski et al., 2008]. Therefore, the pre-Tertiary evolution of the West Carpathians has to be principally correlated with the Eastern Alps. According to Schmid et al., [2008] such correlation contends with considerable difficulties due to along strike changes in the architecture of the Eo-Alpine orogen and absence of Eo-Alpine high-pressure rocks in the West Carpathians. On the other hand, the correlation of the Gemer-Upper Austroalpine and VeporMiddle Austroalpine [e.g., Neubauer et al., 2000] is justified by similar pre-Variscan, Variscan and Permian-Triassic evolutions of both regions [Plašienka et al., 1997; Thöni, 1999; Jeřábek et al., 2008b]. Furthermore, the "absent" Eo-Alpine high-pressure rocks in the West Carpathians could be sought in the Vepor Unit characterized by a relatively cold Cretaceous metamorphic field gradient with maximum P-T conditions of $1.1 \mathrm{GPa}$ and $620^{\circ} \mathrm{C}$ [Janák et al., 2001]. The Eo-Alpine high-pressure belt in the Middle Austroalpine of the Eastern Alps consists of numerous rock complexes to the north of the Periadriatic Line, which are characterized by a relatively narrow time span of highpressure metamorphism between 109 and $90 \mathrm{Ma}$ and rapid exhumation accomplished by $\sim 85 \mathrm{Ma}$ [Thöni, 2006]. This timing is in an excellent agreement with the above proposed burial (108-95 Ma) and exhumation (90-83 Ma) of the Vepor Unit. Taking into account northward emplacement of eclogitic nappes in the Eo-Alpine high-pressure Saualpe, Koralpe and Pohorje complexes [Neubauer, 1991; Kurz et al., 2002; Janák et al., 2004] and N-S convergence during the peak metamorphism in the Vepor Unit, we argue that the Vepor Unit represents direct continuation of the EoAlpine high-pressure belt into the West Carpathians.

[51] The character of high-pressure metamorphism in the Eastern Alps points to a subduction of continental crust which is either associated with [e.g., Janák et al., 2004; Schmid et al., 2004] or separated from [Stüwe and Schuster, 2010] subduction of the Meliata-Hallstatt ocean. The relatively large gap between the Late Jurassic obduction of Meliata upon the Gemer Unit [Faryad and Henjes-Kunst, 1997] and the onset of Albian-Cenomanian Gemer-Vepor convergence [Hurai et al., 2008] argues for two separate events in the West Carpathians. Furthermore, recent kinematic data from the Meliata high-pressure rocks suggest their westward or northwestward emplacement [e.g., Dallmeyer et al., 2008] indicating that the Jurassic event is also kinematically distinct from the northward Cretaceous thrusting in the Gemer-Vepor system [Lexa et al., 2003]. On the other hand, the overall paleogeographic setup for the Eo-Alpine event is still poorly understood.

[52] The question arises as whether the tectonic evolution of the Vepor Dome can be correlated with the existing models of formation of crustal-scale domal structures. Indeed, the absence of back-arc type tectonic environment perpendicular to the orogenic front in the West Carpathians rule out the core complex model of Aegean or Basin and Range type. The gravity redistribution origin of gneiss domes typical for the Variscan belt and Canadian Cordillera can be also ruled out due to the lack of inverted density profile and relatively low metamorphic field gradient precluding an activation of Rayleigh-Taylor instability [Lexa et al., 2011]. The metamorphic field gradient in the Vepor Dome together with the orientation of lineation and geometry of the dominant planar fabric (Figure 3) are consistent with the model of orogen-parallel extension described in the Tauern Window. On the other hand, the principal specific feature of the Vepor Dome is that its subhorizontal foliation and orogen parallel stretching lineation are related to prograde metamorphic evolution associated with burial [Jeŕábek et al., 2008a] and not exhumation as it is typical for the orogen parallel extensional domes [e.g., Selverstone and Spear, 1985].

[53] We propose that the E-W orogen parallel flow within the dense but mechanically weak metapelites of the Veporic lower crust occurred due to progressive development of the orogenic front parallel pressure gradient related to overthrusting of the Gemer Unit from the south. As the lower crustal flow occurs synchronously with the upper crustal thickening, this process can be understood as an "inverse" ductile thinning of the orogenic lower crust. The subsequent exhumation of the Vepor basement is related to the progression in underthrusting of the Fatric crustal wedge from the north inducing a polyharmonic folding in the deep Veporic crust. The fold amplification and overall growth of the Vepor Dome was accompanied by upper crustal detachment faulting and ductile thinning responsible for eastward unroofing of the Vepor Unit.

[54] Acknowledgments. This work was supported by the research grant from the Czech Science Foundation GACR 205/09/1041 and the Ministry of Education, Youth and Sports of the Czech Republic Research Plan MSM0021620855. D.P. is grateful for the support of the Scientific Grant Agency VEGA (project 1/0388/10) and of the Slovak Research and Development Agency (project APVV-0465-06). Laurent Jolivet and Liviu Matenco are thanked for their constructive reviews which greatly helped to improve the clarity of the present paper. Onno Oncken and Claudio Faccenna are thanked for their careful editorial handling.

\section{References}

Allemand, P., and J. M. Lardeaux (1997), Strain partitioning and metamorphism in a deformable orogenic wedge: Application to the Alpine belt Tectonophysics, 280(1-2), 157-169, doi:10.1016/S0040-1951(97)00136-4. Beaumont, C., M. H. Nguyen, R. A. Jamieson, and S. Ellis (2006), Crustal flow modes in large hot orogens, in Channel Flow Ductile Extrusion and Exhumation in Continental Collision Zones, edited by R. Law, M. Searle, and L. Godin, Geol. Soc. Spec. Publ., 268, 91-145, doi:10.1144/GSL. SP.2006.268.01.05

Beltrando, M., G. Lister, J. Hermann, M. Forster, and R. Compagnoni (2008), Deformation mode switches in the Penninic units of the Urtier Valley (Western Alps): Evidence for a dynamic orogen, J. Struct. Geol., 30(2), 194-219, doi:10.1016/j.jsg.2007.10.008.

Bezák, V., S. Jacko, M. Janák, P. Ledru, I. Petrík, and A. Vozárová (1997), Main Hercynian lithotectonic units of the Western Carpathians, in Geological Evolution of the Western Carpathians, edited by P. Grecula, D. Hovorka, and M. Putiš, pp. 261-268, Mineral. Slovaca Corp., Bratislava. Bibikova, E. V., S. P. Korikovsky, M. Putiš, I. Broska, Y. V. Goltzman, and M. Arakeliants (1990), U-Pb, Rb-Sr and K-Ar dating of Sihla tonalites of Vepor Pluton (Western Carpathian Mts.), Geol. Zb. Geol. Carpathica, 41(4), $427-436$.

Bielik, M., J. Šefara, M. Kováč, V. Bezák, and D. Plašienka (2004), The Western Carpathians-Interaction of Hercynian and Alpine processes, Tectonophysics, 393(1-4), 63-86, doi:10.1016/j.tecto.2004.07.044.

Biely, A. (1964), Ueber die "Veporiden, Geol. Zb. Geol. Carpathica, 15, 263-266. 
Bird, P. (1991), Lateral extrusion of lower crust from under high topography in the isostatic limit, J. Geophys. Res., 96(B6), 10,275-10,286, doi:10.1029/91JB00370.

Brown, E. H., and J. L. Talbot (1989), Orogen-parallel extension in the North Cascades crystalline core, Washington, Tectonics, 8(6), 1105-1114 doi:10.1029/TC008i006p01105.

Bukovská, Z., P. Jeřábek, O. Lexa, J. Konopásek, M. Janák, and J. Košler (2012), Kinematically unrelated C-S fabrics: An example of extensional shear band cleavage from the Vepor Unit, West Carpathians, Geol. Carpathica, in press.

Burg, J.-P., J. Vandendriesche, and J. P. Brun (1994), Syn-thickening to post-thickening extension - mode and consequences, C. R. Acad. Sci. Ser. II, 319(9), 1019-1032.

Burg, J.-P., B. J. P. Kaus, and Y. Y. Podladchikov (2004), Dome structures in collision orogens: Mechanical investigation of the gravity/compression interplay, in Gneiss Domes in Orogeny, edited by D. Whitney, C. Teyssier, and C. Siddoway, Spec. Pap. Geol. Soc. Am., 380, 47-66, doi:10.1130/ 0-8137-2380-9.47.

Clark, M., and L. H. Royden (2000), Topographic ooze: Building the eastern margin of Tibet by lower crustal flow, Geology, 28, 703-706, doi:10.1130/0091-7613(2000)28<703:TOBTEM $>2.0 . C O ; 2$

Coggon, R., and T. J. B. Holland (2002), Mixing properties of phengitic micas and revised garnet-phengite thermobarometers, J. Metamorph. Geol., 20(7), 683-696, doi:10.1046/j.1525-1314.2002.00395.x.

Coney, P. (1987), The regional tectonic setting and possible causes of Cenozoic extension in the North American Cordillera, in Continental Extensional Tectonics, edited by M. Coward, J. Dewey, and P. Hancock, Geol. Soc. Spec. Publ., 28, 177-186, doi:10.1144/GSL.SP.1987.028.01.13.

Connolly, J. A. D. (2005), Computation of phase equilibria by linear programming: A tool for geodynamic modeling and its application to subduction zone decarbonation, Earth Planet. Sci. Lett., 236(1-2), 524-541, doi:10.1016/j.epsl.2005.04.033.

Dallmeyer, R. D., F. Neubauer, and M. Putiš (1993), ${ }^{40} \mathrm{Ar} /{ }^{39} \mathrm{Ar}$ mineral age controls for the Pre-Alpine and Alpine tectonic evolution of nappe complexes in the Western Carpathians, in Pre-Alpine Events in the Western Carpathians Realm, Conference Excursion Guide, Stará Lesná, edited by P. Pitoňák and J. Spišiak, pp. 11-20, PUBLISHER, LOCATION.

Dallmeyer, R. D., F. Neubauer, R. Handler, H. Fritz, W. Mueller, D. Pana, and M. Putiš (1996), Tectonothermal evolution of the internal Alps and Carpathians; evidence from ${ }^{40} \mathrm{Ar} /{ }^{39} \mathrm{Ar}$ mineral and whole-rock data, in Alpine Geology; Proceedings of the Second Workshop., vol. 89, edited by S. M. Schmid et al., pp. 203-227, Birkhaeuser, Basel.

Dallmeyer, R. D., Z. Németh, and M. Putiš (2005), Regional tectonothermal events in Gemericum and adjacent units (Western Carpathians, Slovakia) Contribution by the ${ }^{40} \mathrm{Ar} /{ }^{39} \mathrm{Ar}$ dating, Slovak Geol. Mag., 11, 155-163.

Dallmeyer, R. D., F. Neubauer, and H. Fritz (2008), The Meliata suture in the Carpathians: Regional significance and implications for the evolution of high-pressure wedges within collisional orogens, in Tectonic Aspects of the Alpine-Dinaride-Carpathian System, edited by S. Siegesmund, B. Fügenschuh, and N. Froitzheim, Geol. Soc. Spec. Publ., 298, 101-115, doi:10.1144/SP298.6.

Danišík, M., M. Kohút, I. Broska, and W. Frisch (2010), Thermal evolution of the Malá Fatra Mountains (Central Western Carpathians): Insights from zircon and apatite fission track thermochronology, Geol. Carpathica, 61(1), 19-27, doi:10.2478/v10096-009-0041-0.

Dewey, J. F., S. Cande, and W. C. Pitman (1989), Tectonic evolution of the India Eurasia collision zone, Eclogae Geol. Helv., 82(3), 717-734.

Duclaux, G., P. Rey, S. Guillot, and R.-P. Ménot (2007), Orogen-parallel flow during continental convergence: Numerical experiments and Archean field examples, Geology, 35(8), 715-718, doi:10.1130/G23540A.1.

Faryad, S. W. (1991), Pre-Alpine metamorphic events in Gemericum, Miner. Slovaca, 23(5-6), 395-402.

Faryad, S. W., and F. Henjes-Kunst (1997), Petrological and K-Ar and ${ }^{40} \mathrm{Ar}^{-39} \mathrm{Ar}$ age constraints for the tectonothermal evolution of the highpressure Meliata unit, Western Carpathians (Slovakia), Tectonophysics, 280(1-2), 141-156, doi:10.1016/S0040-1951(97)00141-8.

Fügenschuh, B., and S. M. Schmid (2005), Age and significance of core complex formation in a very curved orogen: Evidence from fission track studies in the South Carpathians (Romania), Tectonophysics, 404(1-2), 33-53, doi:10.1016/j.tecto.2005.03.019.

Henk, A. (1999), Did the Variscides collapse or were they torn apart?: A quantitative evaluation of the driving forces for postconvergent extension in central Europe, Tectonics, 18(5), 774-792, doi:10.1029/1999TC900014.

Hók, J., P. Kováč, and J. Madarás (1993), Extensional tectonics of the western part of the contact area between Veporicum and Gemericum [in Slovak], Miner. Slovaca, 25(3), 172-176.

Holland, T., J. Baker, and R. Powell (1998), Mixing properties and activitycomposition relationships of chlorites in the system $\mathrm{MgO}-\mathrm{FeO}-\mathrm{Al}_{2} \mathrm{O}_{3}$ $\mathrm{SiO}_{2}-\mathrm{H}_{2} \mathrm{O}$, Eur. J. Mineral., 10(3), 395-406.
Hraško, L., J. Határ, H. Huhma, I. Mantari, and J. Michalko (1999), U/Pb zircon dating of the Upper Cretaceous granite (Rochovce type) in the Western Carpathians, Krystalinikum, 25, 163-171.

Hrouda, F., and K. Schulmann (1990), Conversion of the magnetic susceptibility tensor into the orientation tensor in some rocks, Phys. Earth Planet. Inter., 63(1-2), 71-77, doi:10.1016/0031-9201(90)90061-2.

Hrouda, F., M. Putiš, and J. Madarás (2002), The Alpine overprints of the magnetic fabrics in the basement and cover rocks of the Veporic Unit (Western Carpathians, Slovakia), Tectonophysics, 359(3-4), 271-288, doi:10.1016/S0040-1951(02)00515-2.

Huet, B., L. Le Pourhiet, L. Labrousse, E. Burov, and L. Jolivet (2011), Post-orogenic extension and metamorphic core complexes in a heterogeneous crust: The role of crustal layering inherited from collision. Application to the Cyclades (Aegean domain), Geophys. J. Int., 184(2), 611-625, doi:10.1111/j.1365-246X.2010.04849.x.

Hurai, V. (1983), Genetic interpretation of gas-fluid inclusions within Alpine quartz veins in the Veporic crystalline unit [in Slovak], Miner. Slovaca, 15(3), 243-260.

Hurai, V., O. Lexa, K. Schulmann, R. Montigny, W. Prochaska, W. Frank, P. Konečný, J. Král', R. Thomas, and M. Chovan (2008), Mobilization of ore fluids during Alpine metamorphism: Evidence from hydrothermal veins in the Variscan basement of Western Carpathians, Slovakia, Geofluids, 8(3), 181-207, doi:10.1111/j.1468-8123.2008.00216.x.

Jacko, S., T. Sasvari, M. Zacharov, R. Schmidt, and J. Vozár (1996), Contrasting styles of Alpine deformations at the eastern part of the Veporicum and Gemericum units, Western Carpathians, Slovak Geol. Mag. 2, 151-164.

Janák, M., D. Plašienka, M. Frey, M. Cosca, S. T. Schmidt, B. Lupták, and Š. Méres (2001), Cretaceous evolution of a metamorphic core complex, the Veporic unit, Western Carpathians (Slovakia): P-T conditions and in situ ${ }^{40} \mathrm{Ar} /{ }^{39} \mathrm{Ar}$ UV laser probe dating of metapelites, J. Metamorph. Geol., 19(2), 197-216, doi:10.1046/j.0263-4929.2000.00304.x.

Janák, M., N. Froitzheim, B. Lupták, M. Vrabec, and E. Ravna (2004), First evidence for ultrahigh-pressure metamorphism of eclogites in Pohorje, Slovenia: Tracing deep continental subduction in the Eastern Alps, Tectonics, 23, TC5014, doi:10.1029/2004TC001641.

Janák, M., Š. Méres, and P. Ivan (2007), Petrology and metamorphic P-T conditions of eclogites from the northern Veporic Unit (Western Carpathians, Slovakia), Geol. Carpathica, 58(2), 121-131.

Jeřábek, P., H. Stünitz, R. Heilbronner, O. Lexa, and K. Schulmann (2007), Microstructural-deformation record of an orogen-parallel extension in the Vepor Unit, West Carpathians, J. Struct. Geol., 29(11), 1722-1743, doi:10.1016/j.jsg.2007.09.002.

Jeřábek, P., W. S. Faryad, K. Schulmann, O. Lexa, and L. Tajčmanová (2008a), Alpine burial and heterogeneous exhumation of Variscan crust in the West Carpathians: Insight from thermodynamic and argon diffusion modelling, J. Geol. Soc., 165(2), 479-498, doi:10.1144/0016$76492006-165$.

Jeřábek, P., M. Janák, S. W. Faryad, F. Finger, and P. Konečný (2008b), Polymetamorphic evolution of pelitic schists and evidence for Permian lowpressure metamorphism in the Vepor Unit, West Carpathians, J. Metamorph. Geol., 26(4), 465-485, doi:10.1111/j.1525-1314.2008.00771.x.

Ježek, J., and F. Hrouda (2007), SUSIE: A program for inverse strain estimation from magnetic susceptibility, Comput. Geosci., 33(6), 749-759, doi:10.1016/j.cageo.2006.11.002.

Jolivet, L., J. P. Brun, P. Gautier, S. Lallemant, and M. Patriat (1994), 3D-kinematics of extension in the Aegean region from the early Miocene to the present; insights from the ductile crust, Bull. Soc. Geol. Fr., 165(3), 195-209.

Kali, E., P. H. Leloup, N. Arnaud, G. Mahéo, D. Liu, E. Boutonnet, J. Van der Woerd, X. Liu, J. Liu-Zeng, and H. Li (2010), Exhumation history of the deepest central Himalayan rocks, Ama Drime range: Key pressuretemperature-deformation-time constraints on orogenic models, Tectonics, 29(2), TC2014, doi:10.1029/2009TC002551.

Kamenický, J. (1977), Contact metamorphism in the aureole of the Rimavica granite (West Carpathian Mts.), Miner. Slovaca, 9(3), 161-240.

Kissová, D., I. Dunkl, D. Plašienka, W. Frisch, and R. Marschalko (2005), The Pieninic exotic cordillera (Andrusov Ridge) revisited: New zircon FT ages of granite pebbles from Cretaceous flysch conglomerates of the Pieniny Klippen Belt (Western Carpathians, Slovakia), Slovak Geol. Mag., 11, 17-28.

Klinec, A. (1966), On the structure and evolution of the Veporic crystalline unit [in Slovak], Zb. Geol. Vied Zapadne Karpaty, 6, 7-28.

Kováčik, M., J. Král', and H. Maluski (1996), Metamorphic rocs in the Southern Veporicum basement: Their Alpine metamorphism and thermochronologic evolution [in Slovak], Miner. Slovaca, 28(3), 185-202.

Kozur, H., and R. Mock (1973), Zum Alter und zur tektonischen Stellung der Meliata-Serie des Slowakischen Karstes, Geol. Zb. Geol. Carpathica, $24,365-374$ 
Kozur, H., and R. Mock (1997), New paleogeographic and tectonic interpretations in the Slovakian Carpathians and their implications for correlations with the Eastern Alps. Part II: Inner Western Carpathians, Miner. Slovaca, 29, 164-209.

Kozur, H., R. Mock, and H. Mostler (1976), Stratigraphische Neueinstufung der Karbonatgesteine der unteren Schichtenfolge von Ochtiná in das oberste Vise derpukhovian (Namur A), Geol. Palaeontol. Mitt., 6(1), $1-29$.

Král', J. (1977), Fission track ages of apatites from some granitoid rocks in West Carpathians, Geol. Zb. Geol. Carpathica, 28(2), 269-276.

Král', J., D. Štarková, V. Bezák, M. Kováčik, and D. Zatovič (1995), ${ }^{40} \mathrm{Ar}^{39} \mathrm{Ar}$ Dating of Selected Minerals of the Tatra and Vepor Crystalline Basement, Geol. Ústav Dionýza Štúra, Bratislava.

Kretz, R. (1983), Symbols for rock-forming minerals, Am. Mineral., 68(1-2), 277-279.

Kubeš, P., V. Bezák, L. Kucharič, M. Filo, J. Vozár, V. Konečný, M. Kohút, and A. Gluch (2010), Magnetic field of the Western Carpathians (Slovakia): Reflections on the structure of the crust, Geol. Carpathica, 61(5), 437-447, doi:10.2478/v10096-010-0026-z.

Kurz, W., H. Fritz, V. Tenczer, and W. Unzog (2002), Tectonometamorphic evolution of the Koralm Complex (Eastern Alps): Constraints from microstructures and textures of the "Plattengneis" shear zone, J. Struct. Geol., 24(12), 1957-1970, doi:10.1016/S0191-8141(02)00008-1.

Lexa, O., K. Schulmann, and J. Ježek (2003), Cretaceous collision and indentation in the West Carpathians: View based on structural analysis and numerical modeling, Tectonics, 22(6), 1066, doi:10.1029/ 2002 TC001472.

Lexa, O., K. Schulmann, V. Janoušek, P. Štípská, A. Guy, and M. Racek (2011), Heat sources and trigger mechanisms of exhumation of HP granulites in Variscan orogenic root, J. Metamorph. Geol., 29(1), 79-102, doi:10.1111/j.1525-1314.2010.00906.x

Lister, G. S., and G. A. Davis (1989), The origin of metamorphic core complexes and detachment faults formed during Tertiary continental extension in the northern Colorado River region, USA, J. Struct. Geol., 11(1-2), 65-94, doi:10.1016/0191-8141(89)90036-9.

Lister, G. S., and B. E. Hobbs (1980), The simulation of fabric development during plastic-deformation and its application to quartzite - the influence of deformation history, J. Struct. Geol., 2(3), 355-370, doi:10.1016/ 0191-8141(80)90023-1.

Lister, G. S., G. Banga, and A. Feenstra (1984), Metamorphic core complexes of Cordilleran type in the Cyclades, Aegean Sea, Greece, Geology, 12(4), 221-225, doi:10.1130/0091-7613(1984)12<221:MCCOCT $>2.0$ $\mathrm{CO} ; 2$.

Lupták, B., M. Janák, D. Plašienka, S. T. Schimdt, and M. Frey (2000), Chloritoid-kyanite schists from the Veporic unit, Western Carpathians, Slovakia: Implications for Alpine (Cretaceous) metamorphism, Schweiz. Mineral. Petrogr. Mitt., 80(2), 213-223.

Lupták, B., M. Janák, D. Plašienka, and S. T. Schimdt (2003), Alpine low grade metamorphism of the Permian-Triassic sedimentary rocks from the Veporic superunit, Western Carpathians: Phyllosilicate composition and "crystallinity" data, Geol. Carpathica, 54(6), 367-375.

Lupták, B., M. Thöni, M. Janák, and I. Petrik (2004), Sm-Nd isotopic chronometry of garnets from the Veporic Unit, Western Carpathians: Some preliminary age results and P-T constraints, Geolines, 17, 66.

Madarás, J., M. Putiš, and B. Dubík (1994), Structural characteristics of the middle part of the Pohorelá tectonic zone [in Slovak], Miner. Slovaca, 26(3), 177-191.

Maluski, H., P. Rajlich, and P. Matte (1993), 40Ar - 39Ar dating of the Inner Carpathians Variscan basement and Alpine mylonitic overprinting, Tectonophysics, 223(3-4), 313-337, doi:10.1016/0040-1951(93)90143-8.

Mancktelow, N. S., and T. L. Pavlis (1994), Fold-fault relationships in lowangle detachment systems, Tectonics, 13(3), 668-685, doi:10.1029/ 93TC03489.

Mariani, E., K. H. Brodie, and E. H. Rutter (2006), Experimental deformation of muscovite shear zones at high temperatures under hydrothermal conditions and the strength of phyllosilicate-bearing faults in nature, J. Struct. Geol., 28(9), 1569-1587, doi:10.1016/j.jsg.2006.06.009.

McKenzie, D., F. Nimmo, J. A. Jackson, P. Gans, and E. Miller (2000), Characteristics and consequences of flow in the lower crust, J. Geophys. Res., 105(B5), 11,029-11,046, doi:10.1029/1999JB900446.

Méres, S., and D. Hovorka (1991), Alpine metamorphic recrystallization of the pre-Carboniferous metapelites of the Kohút crystalline complex (the Western Carpathians), Miner. Slovaca, 23(5-6), 435-442.

Michalko, J., V. Bezák, L. Hraško, J. Král', H. Huhma, I. Mantari, M. Vaasjoki, I. Broska, and J. Határ (1998), U/Pb zircon data of the Veporic granitoids (Western Carpathians), Krystalinikum, 24, 91-104.

Moussallam, Y., D. A. Schneider, M. Janák, M. Thöni, and D. K. Holm (2012), Heterogeneous extrusion and exhumation of deep-crustal
Variscan assembly: Geochronology of the Western Tatra Mountains, northern Slovakia, Lithos, 144-145, 88-108, doi:10.1016/j.lithos.2012. 03.025 .

Neubauer, F. (1991), Kinematic indicators in the Koralm and Saualm eclogites (Eastern Alps), Zb. Geol. Palaeontol., I(1), 139-155.

Neubauer, F., J. Genser, and R. Handler (2000), The Eastern Alps: Result of a two-stage collision process, Mitt. Oesterr. Geol. Ges., 92, 117-134.

Newton, R. C., T. V. Charlu, and O. J. Kleppa (1980), Thermochemistry of high structural state plagioclases, Geochim. Cosmochim. Acta, 44, 933-941, doi:10.1016/0016-7037(80)90283-5.

Passchier, C. W., and R. A. J. Trouw (2005), Microtectonics, 2nd ed., Springer, Berlin.

Perchuk, L. L., L. Y. Aranovich, K. K. Podlesskii, I. V. Lavrant'eva, V. Y. Gerasimov, V. V. Fed'kin, V. I. Kitsul, L. P. Karsakov, and N. V. Berdnikov (1985), Precambrian granulites of the Aldan shield, eastern Siberia, USSR, J. Metamorph. Geol., 3(3), 265-310, doi:10.1111/ j.1525-1314.1985.tb00321.x.

Plašienka, D. (1993), Structural pattern and partitioning of deformation in the Veporic Foederata cover unit (Central Western Carpathians), in Geodynamic Model and Deep Structure of the Western Carpathians, edited by M. Rakús and J. Vozár, pp. 269-277, Geol. Ústav Dionýza Stúra, Bratislava.

Plašienka, D. (1995a), Cleavages and folds in changing tectonic regimes: The Vel'ký Bok Mesozoic cover unit of the Veporicum (Nízke Tatry Mts., Central Western Carpathians), Slovak Geol. Mag., 2, 97-113.

Plašienka, D. (1995b), Passive and active margin history of the northern Tatricum (Western Carpathians, Slovakia), Geol. Rundsch., 84(4), 748-760, doi:10.1007/BF00240565.

Plašienka, D. (2003), Development of basement-involved fold and thrust structures exemplified by the Tatric-Fatric-Veporic nappe system of the Western Carpathians (Slovakia), Geodin. Acta, 16(1), 21-38, doi:10.1016/ S0985-3111(02)00003-7.

Plašienka, D., and J. Soták (2001), Stratigraphic and tectonic position of Carboniferous sediments in the Furmanec Valley (Muráň Plateau, Central Western Carpathians), Miner. Slovaca, 33(1), 29-44.

Plašienka, D., M. Janák, and A. Hacura (1989), First illite-crystalinity data from Alpine metamorphosed rocks of the Veporicum, Central West Carpathians [in Slovak], Miner. Slovaca, 21(1), 43-51.

Plašienka, D., P. Grecula, M. Putiš, M. Kováč, and D. Hovorka (1997), Evolution and structure of the Western Carpathians: An overview, in Geological Evolution of the Western Carpathians, edited by P. Grecula, D. Hovorka, and M. Putiš, pp. 1-24, Mineral. Slovaca Corp., Bratislava. Plašienka, D., I. Broska, D. Kissová, and I. Dunkl (2007), Zircon fission-track datings of granites from the Vepor-Gemer Belt (Western Carpathians) Constraints for the Early Alpine exhumation history, J. Geosci. (Prague), 52(1-2), 113-123, doi:10.3190/jgeosci.009.

Platt, J. P. (1986), Dynamics of orogenic wedges and the uplift of highpressure metamorphic rocks, Geol. Soc. Am. Bull., 97(9), 1037-1053, doi:10.1130/0016-7606(1986)97<1037:DOOWAT>2.0.CO;2.

Platt, J. P. (2007), From orogenic hinterlands to Mediterranean-style backarc basins: A comparative analysis, J. Geol. Soc., 164(2), 297-311, doi:10.1144/0016-76492006-093.

Poller, U., P. Uher, M. Janák, D. Plašienka, and M. Kohút (2001), Late Cretaceous age of the Rochovce Granite, Western Carpathians, constrained by $\mathrm{U}-\mathrm{Pb}$ single-zircon dating in combination with cathodoluminescence imaging, Geol. Carpathica, 52(1), 41-47.

Prokešová, R., D. Plašienka, and R. Milovský (2012), Structural pattern and emplacement mechanisms of the Krížna cover nappe (Central Western Carpathians), Geol. Carpathica, 63(1), 13-32, doi:10.2478/v10096-0120001-y

Putiš, M. (1991), Geology and petrotectonics of some shear zones in the West Carpathian crystalline complexes, Miner. Slovaca, 23(5-6), 459-473. Putiš, M., I. Filová, S. P. Korikovsky, A. B. Kotov, and J. Madarás (1997a), Layered metaigneous complex of the Veporic basement with features of the Variscan and Alpine thrust tectonics (the Western Carpathians), in Geological Evolution of the Western Carpathians, edited by P. Grecula, D. Hovorka, and M. Putiš, pp. 176-196, Mineral. Slovaca Corp., Bratislava. Putiš, M., W. Unzog, E. Wallbrecher, and H. Fritz (1997b), Mylonitization and chemical mass-transfer in granitoid rocks of the Vepor pluton near the Cretaceous Pohorelá thrust (Veporic unit, central Western Carpathians), in Geological Evolution of the Western Carpathians, edited by P. Grecula D. Hovorka, and M. Putiš, pp. 197-214, Mineral. Slovaca Corp., Bratislava.

Putiš, M., W. Frank, D. Plašienka, P. Siman, M. Sulál, and A. Biroň (2009), Progradation of the Alpidic Central Western Carpathians orogenic wedge related to two subductions: Constrained by ${ }^{40} \mathrm{Ar} /{ }^{39} \mathrm{Ar}$ ages of white micas, Geodin. Acta, 22(1-3), 31-56, doi:10.3166/ga.22.31-56.

Ramsay, J. G. (1967), Folding and Fracturing of Rocks, McGraw-Hill, New York. 
Ratschbacher, L., W. Frisch, H.-G. G. Linzer, and O. Merle (1991), Lateral extrusion in the Eastern Alps, Part 2: Structural analysis, Tectonics, 10(2), 257-271, doi:10.1029/90TC02623.

Ree, J. H. (1991), An experimental steady-state foliation, J. Struct. Geol., 13(9), 1001-1011, doi:10.1016/0191-8141(91)90052-K.

Rozlozsnik, P. (1935), Die Geologische Verhältnisse der gegend von Dobšiná, Geol. Hung., 5, 1-118.

Scheidegger, A. (1965), On the statistics of the orientation of bedding planes, grain axes, and similar sedimentological data, U.S. Geol. Surv. Prof. Pap., 525-C, 164-167.

Schmid, S. M., and M. Casey (1986), Complete fabric analysis of some commonly observed quartz [c]-axis patterns, in Mineral and Rock Deformation: Laboratory Studies, Geophys. Monogr. Ser., vol. 36, edited by B. E. Hobbs and H. C. Heard, pp. 263-286, AGU, Washington D. C.

Schmid, S. M., T. Berza, V. Diaconescu, N. Froitzheim, and B. Fugenschuh (1998), Orogen-parallel extension in the Southern Carpathians, Tectonophysics, 297(1-4), 209-228, doi:10.1016/S0040-1951(98)00169-3.

Schmid, S. M., B. Fügenschuh, E. Kissling, and R. Schuster (2004) Tectonic map and overall architecture of the Alpine orogen, Eclogae Geol. Helv., 97(1), 93-117, doi:10.1007/s00015-004-1113-x.

Schmid, S. M., D. Bernoulli, B. Fügenschuh, L. Matenco, S. Schefer, R. Schuster, M. Tischler, and K. Ustaszewski (2008), The AlpineCarpathian-Dinaridic orogenic system: Correlation and evolution of tectonic units, Swiss J. Geosci., 101(1), 139-183, doi:10.1007/s00015008-1247-3

Selverstone, J. (1988), Evidence for east-west crustal extension in the Eastern Alps: Implications for the unroofing history of the Tauern window, Tectonics, 7(1), 87-105, doi:10.1029/TC007i001p00087.

Selverstone, J., and F. S. Spear (1985), Metamorphic P-T paths from pelitic schists and greenstones from the south-west Tauern Window, Eastern Alps, J. Metamorph. Geol., 3(4), 439-465, doi:10.1111/j.1525-1314.1985. tb00329.x.

Seyferth, M., and A. Henk (2004), Syn-convergent exhumation and lateral extrusion in continental collision zones-Insights from three-dimensional numerical models, Tectonophysics, 382(1-2), 1-29, doi:10.1016/j.tecto. 2003.12.004

Siman, P., V. Johan, P. Ledru, V. Bezák, and J. Madarás (1996), Deformation and P-T conditions estimated in "layered migmatites" from southern part of Veporicum crystalline basement (Western Carpathians, Slovakia), Slovak Geol. Mag., 3-4, 209-213.

Soták, J., A. Vozárová, and J. Ivanička (1999), New microfossils from the early Paleozoic formations of the Gemericum (Foraminiferida), Geol. Carpathica, 50, 72-74.

Stüwe, K., and R. Schuster (2010), Initiation of subduction in the Alps: Continent or ocean?, Geology, 38(2), 175-178, doi:10.1130/G30528.1.

Teyssier, C., and D. L. Whitney (2002), Gneiss domes and orogeny, Geology, 30(12), 1139-1142, doi:10.1130/0091-7613(2002)030<1139:GDAO>2.0. $\mathrm{CO} ; 2$.

Thöni, M. (1999), A review of geochronological data from the Eastern Alps, Schweiz. Mineral. Petrogr. Mitt., 79(1), 209-230.

Thöni, M. (2006), Dating eclogite-facies metamorphism in the Eastern Alps-Approaches, results, interpretations: A review, Mineral. Petrol., 88(1-2), 123-148, doi:10.1007/s00710-006-0153-5.
Tikoff, B., C. Teyssier, and C. Waters (2002), Clutch tectonics and the partial attachment of lithospheric layers, in Continental Collision and the Tectono-Sedimentary Evolution of Forelands, edited by G. Bertotti, K. Schulmann, and S. A. P. L. Cloetingh, pp. 57-73, Copernicus, Katlenburg-Lindau, Germany, doi:10.5194/smsps-1-57-2002.

Tomek, C. (1993), Deep crustal structure beneath the central and inner West Carpathians, Tectonophysics, 226(1-4), 417-431, doi:10.1016/00401951(93)90130-C

Turcotte, D. L., and G. Schubert (2002), Geodynamics, 2nd ed., Cambridge Univ. Press, Cambridge, U. K.

Ustaszewski, K., S. M. Schmid, B. Fügenschuh, M. Tischler, E. Kissling, and W. Spakman (2008), A map-view restoration of the AlpineCarpathian-Dinaridic system for the Early Miocene, Swiss J. Geosci. Prague, 101(S1), 273-294, doi:10.1007/s00015-008-1288-7.

Vanderhaeghe, O., J. P. Burg, and C. Teyssier (1999), Exhumation of migmatites in two collapsed orogens: Canadian Cordillera and French Variscides, in Exhumation Processes: Normal Faulting, Ductile Flow and Erosion, edited by U. Ring et al., Geol. Soc. Spec. Publ., 154, 181-204, doi:10.1144/GSL.SP.1999.154.01.08.

Vigneresse, J. L., and J. L. Bouchez (1997), Successive granitic magma batches during pluton emplacement: The case of Cabeza de Araya (Spain), J. Petrol., 38(12), 1767-1776, doi:10.1093/petroj/38.12.1767.

Vozárová, A. (1990), Development of metamorphism in the Gemeric/ Veporic contact zone (Western Carpathians), Geol. Zb. Geol. Carpathica, 41(5), 475-502.

Vozárová, A., and J. Vozár (1988), Late Paleozoic in West Carpathians, Geol. Ústav Dionýza Štúra, Bratislava.

Vrána, S. (1964), Chloritoid and kyanite zone of alpine metamorphism on the boundary of the Gemerides and the Veporides (Slovakia), Krystalinikum, 2, 125-143.

Vrána, S. (1966), Alpidische Metamorphose der Granitoiden und der Foederata Serie im Mittelteil der Veporiden, Zb. Geol. Vied, Zapadne Karpaty, 6, 29-84.

Vrána, S. (1980), Newly formed Alpine garnets in metagranitoids of the Veporides in relation to the structure of the Central zone of the West Carpathians, Cas Mineral. Geol, 25, 41-54.

White, R. W., R. Powell, T. J. B. Holland, and B. A. Worley (2000), The effect of $\mathrm{TiO}_{2}$ and $\mathrm{Fe}_{2} \mathrm{O}_{3}$ on metapelitic assemblages at greenschist and amphibolite facies conditions: Mineral equilibria calculations in the system $\mathrm{K}_{2} \mathrm{O}-\mathrm{FeO}-\mathrm{MgO}-\mathrm{Al}_{2} \mathrm{O}_{3}-\mathrm{SiO}_{2}-\mathrm{H}_{2} \mathrm{O}-\mathrm{TiO}_{2}-\mathrm{Fe}_{2} \mathrm{O}_{3}$, J. Metamorph. Geol., 18(5), 497-511, doi:10.1046/j.1525-1314.2000.00269.x.

White, R. W., R. Powell, and T. J. B. Holland (2001), Calculation of partial melting equilibria in the system $\mathrm{Na}_{2} \mathrm{O}-\mathrm{CaO}-\mathrm{K}_{2} \mathrm{O}-\mathrm{FeO}-\mathrm{MgO}-\mathrm{Al}_{2} \mathrm{O}_{3}$ $\mathrm{SiO}_{2}-\mathrm{H}_{2} \mathrm{O}$ (NCKFMASH), J. Metamorph. Geol., 19(2), 139-153, doi:10.1046/j.0263-4929.2000.00303.x.

White, R. W., R. Powell, and T. J. B. Holland (2007), Progress relating to calculation of partial melting equilibria for metapelites, J. Metamorph. Geol., 25(5), 511-527, doi:10.1111/j.1525-1314.2007.00711.x.

Zhang, P.-Z., et al. (2004), Continuous deformation of the Tibetan Plateau from global positioning system data, Geology, 32(9), 809-812, doi:10.1130/G20554.1. 